Prepared in cooperation with the U.S. Fish and Wildlife Service

Structured Decision Making for Conservation of Bull Trout (Salvelinus confluentus) in Long Creek, Klamath River Basin, South-Central Oregon

Open-File Report 2017-1075 



\section{Structured Decision Making for Conservation of Bull Trout (Salvelinus confluentus) in Long Creek, Klamath River Basin, South-Central Oregon}

By Joseph R. Benjamin, Kevin McDonnell, Jason B. Dunham, William R. Brignon, and James T. Peterson

Prepared in cooperation with the U.S. Fish and Wildlife Service

Open-File Report 2017-1075

U.S. Department of the Interior

U.S. Geological Survey 


\section{U.S. Department of the Interior \\ RYAN K. ZINKE, Secretary}

\section{U.S. Geological Survey \\ William H. Werkheiser, Acting Director}

U.S. Geological Survey, Reston, Virginia: 2017

For more information on the USGS-the Federal source for science about the Earth, its natural and living resources, natural hazards, and the environment-visit https://www.usgs.gov/ or call 1-888-ASK-USGS (1-888-275-8747).

For an overview of USGS information products, including maps, imagery, and publications, visit https:/store.usgs.gov.

Disclaimer: The findings and conclusions in this article are those of the author(s) and do not necessarily represent the views of the U.S. Fish and Wildlife Service.

Any use of trade, firm, or product names is for descriptive purposes only and does not imply endorsement by the U.S. Government.

Although this information product, for the most part, is in the public domain, it also may contain copyrighted materials as noted in the text. Permission to reproduce copyrighted items must be secured from the copyright owner.

\section{Suggested citation:}

Benjamin, J.R., McDonnell, Kevin, Dunham, J.B., Brignon, W.R., and Peterson, J.T., 2017, Structured decision making for conservation of bull trout (Salvelinus confluentus) in Long Creek, Klamath River Basin, south-central Oregon: U.S. Geological Survey Open-Report 2017-1075, 32 p., https://doi.org/10.3133/ofr20171075.

ISSN 2331-1258 (online) 


\section{Contents}

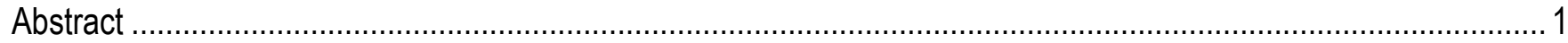

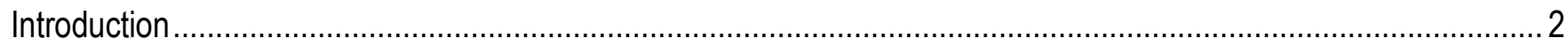

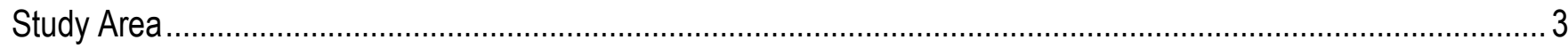

Methods

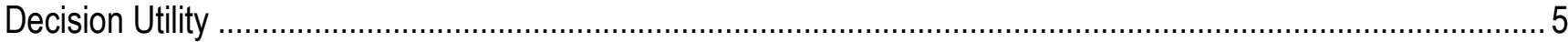

Alternative Management Actions............................................................................................................

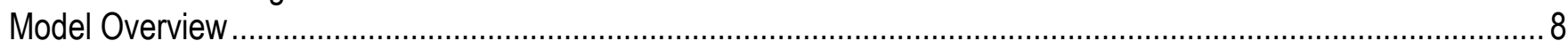

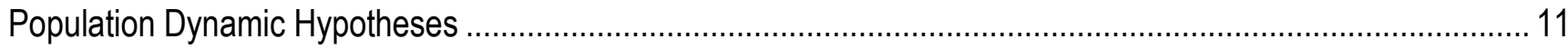

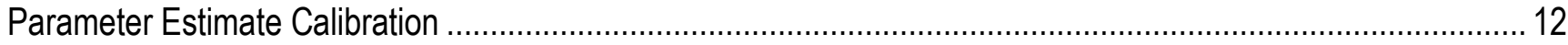

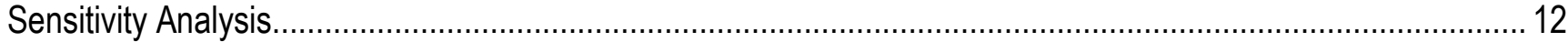

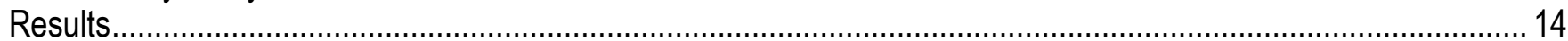

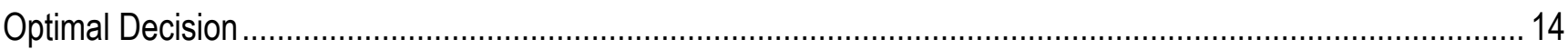

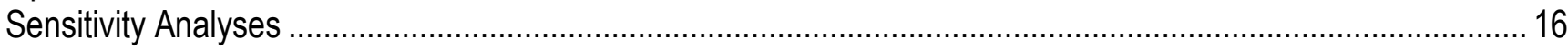

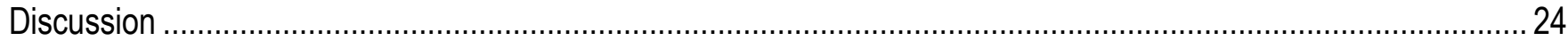

Acknowledgments

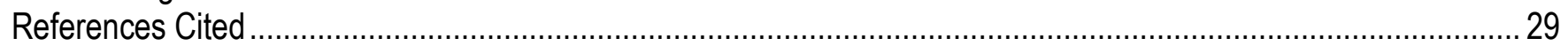

\section{Figures}

Figure 1. Schematics showing Upper Klamath River core areas (outlined with gray) with critical habitat highlighted in thick lines (panel A) and Long Creek watershed in the northern Sycan River Core Area considered in the modeling effort (panel B) ................................................................................................. 4

Figure 2. Diagram showing life cycle for bull trout $(\mathrm{A})$ and brook trout $(\mathrm{B})$.................................................... 9 Figure 3. Graph showing difference in the number of adult bull trout (resident and migrant; black bar) or the marginal gain or loss (gray bar) for each decision relative to not implementing a decision...

Figure 4. Graph showing difference in the number of adult bull trout (resident and migrant) for each decision relative to a no-action decision

Figure 5. Graph showing changes in number of adult bull trout at year 10 based on one-way sensitivity analysis. Values are averaged across the different population dynamic hypotheses

Figure 6. One-way response profiles showing top five decisions and a do nothing scenario under a range of values for (A) survival of adult bull trout migrants, (B) fecundity of adult bull trout migrants, (C) survival of adult bull trout residents, and (D) survival of juvenile brook trout.

Figure 7. Two-way sensitivity analysis lines and shading represent the average number (shown in white boxes along lines) of adult bull trout at year 10 across values of pairs of decision model components, with (A) suggesting that adult resident bull trout survival had a greater influence when migrant adult bull trout survival was assumed to be low, (B) indicating that the utility was sensitive to migrant adult bull trout survival but not to subadult brook trout survival, (C) showing that the utility was equally influenced by migrant subadult and juvenile bull trout survival, and (D) indicating that juvenile brook trout survival had a very minor influence on the utility 
Figure 8. Two-way response profiles showing optimal decisions for select combinations of bull trout and brook trout demographics across a range of values based on maximizing adult abundance

Figure 9. Two-way response profiles showing the optimal decision across a range of transporting bull trout upstream of a barrier compared to a range of bull trout immigrating upstream (A), or an increase in adult bull trout survival owing to improvements downstream (B), and bull trout immigration compared to electrofishing capture efficiency $(C)$

Figure 10. Graphs showing marginal gain of cost of improving downstream conditions relative to cost of eradicating brook trout (A), cost of improving downstream conditions relative to removing brook trout by electrofishing $(B)$, and cost of eradicating brook trout relative to their removal through electrofishing $(C)$

\section{Tables}

Table 1. Alternative management actions and combinations of actions evaluated in the decision model ................ 7

Table 2. Effects of management actions on demographic parameters for bull trout and brook trout....................... 7

Table 3. Demographic parameter values used for bull trout and brook trout matrix models................................. 10

Table 4. Ranked cost from least (1) to most (5) expensive for each alternative management action..................... 14

Table 5. Ranks of potential gains and likelihood of successful implementation for some management objectives and associated actions that could be implemented downstream section of Long Creek and the Sycan River, south-central Oregon.

Table 6. Ranked effects of different management objectives and actions on bull trout and brook trout size and survival

\section{Conversion Factors}

International System of Units to U.S. customary units

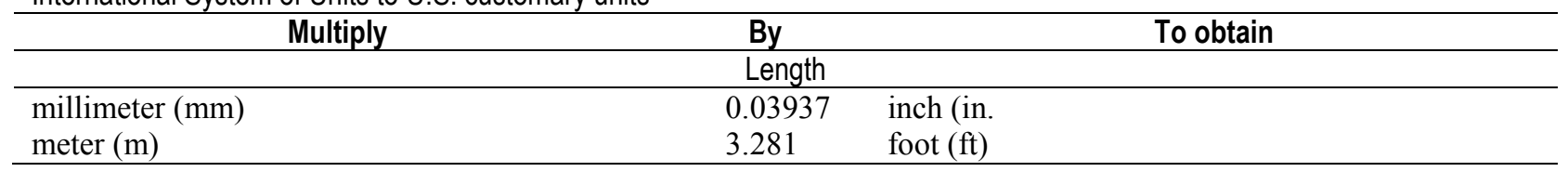

Temperature in degrees Celsius $\left({ }^{\circ} \mathrm{C}\right)$ may be converted to degrees Fahrenheit $\left({ }^{\circ} \mathrm{F}\right)$ as ${ }^{\circ} \mathrm{F}=\left(1.8 \times{ }^{\circ} \mathrm{C}\right)+32$.

\section{Datums}

Vertical coordinate information is referenced to the North American Vertical Datum of 1988 (NAVD 88).

Horizontal coordinate information is referenced to the North American Datum of 1983 (NAD 83).

Altitude, as used in this report, refers to distance above the vertical datum. 


\title{
Structured Decision Making for Conservation of Bull Trout (Salvelinus confluentus) in Long Creek, Klamath River Basin, South-Central Oregon
}

\author{
Joseph R. Benjamin¹, Kevin McDonnell², Jason B. Dunham¹, William R. Brignon³, and James T. Peterson¹
}

\begin{abstract}
With the decline of bull trout (Salvelinus confluentus), managers face multiple, and sometimes contradictory, management alternatives for species recovery. Moreover, effective decision-making involves all stakeholders influenced by the decisions (such as Tribal, State, Federal, private, and nongovernmental organizations) because they represent diverse objectives, jurisdictions, policy mandates, and opinions of the best management strategy. The process of structured decision making is explicitly designed to address these elements of the decision making process. Here we report on an application of structured decision making to a population of bull trout believed threatened by high densities of nonnative brook trout ( $S$. fontinalis) and habitat fragmentation in Long Creek, a tributary to the Sycan River in the Klamath River Basin, south-central Oregon. This involved engaging stakeholders to identify (1) their fundamental objectives for the conservation of bull trout, (2) feasible management alternatives to achieve their objectives, and (3) biological information and assumptions to incorporate in a decision model. Model simulations suggested an overarching theme among the top decision alternatives, which was a need to simultaneously control brook trout and ensure that the migratory tactic of bull trout can be expressed. More specifically, the optimal management decision, based on the estimated adult abundance at year 10, was to combine the eradication of brook trout from Long Creek with improvement of downstream conditions (for example, connectivity or habitat conditions). Other top decisions included these actions independently, as well as electrofishing removal of brook trout. In contrast, translocating bull trout to a different stream or installing a barrier to prevent upstream spread of brook trout had minimal or negative effects on the bull trout population. Moreover, sensitivity analyses suggested that these actions were consistently identified as optimal across a large range of parameter values. Taken together, these results support the conclusion that management actions focused on controlling brook trout and enhancing migrant bull trout are more likely to yield more adult bull trout within the 10-year time frame specified by stakeholders.
\end{abstract}

\footnotetext{
${ }^{1}$ U.S. Geological Survey.

${ }^{2}$ Oregon State University.

${ }^{3}$ U.S. Fish and Wildlife Service.
} 


\section{Introduction}

Bull trout (Salvelinus confluentus) populations have declined throughout their native range, resulting in listing the species as threatened under the Endangered Species Act (U.S. Fish and Wildlife Service, 2015a; Kovach and others, 2016). Primary threats linked to the decline of bull trout populations include loss of connectivity because of physical barriers, effects of past and present land-use practices on physical habitat in streams (for example, availability of pools, suitable spawning substrates), decreases in water quantity and quality, and introduction of nonnative species, all of which have led to increased fragmentation of habitat (defined as a simultaneous loss of habitat size and connectivity; Fahrig, 2003; U.S. Fish and Wildlife Service, 2015a). Among the factors contributing to resilience of bull trout in the face of these threats, as well as natural disturbances, is variability in life history expression (Rieman and McIntyre, 1993). Like many salmonids, bull trout exhibit 'partial migration' which refers to life histories where some individuals complete their life cycle within natal habitats (that is, resident life history), and others migrate to exploit growth opportunities outside natal areas (that is, migratory life history; Brenkman and Corbett, 2005; Dunham and others, 2008). The ability of bull trout to express a migratory life history is thought to provide a buffer against localized natural disturbance (Rieman and McIntyre, 1993; U.S. Fish and Wildlife Service, 2008). For example, 1 year following a wildfire and debris flow that extirpated the resident (non-migratory) fish population in a stream in the Boise River Basin, Idaho, migratory bull trout repopulated the stream (Rieman and others, 1997). Another advantage of migratory life history expression can be substantially increased fecundity in females, owing to their larger body size, and competitive ability in males (for example, Kendall and others, 2015). Thus, reduction in the migratory life history owing to fragmentation and poor fish passage can have implications for the population as a whole. Population declines can be further exacerbated by the presence of nonnative fish, such as brook trout ( $S$. fontinalis), because of competition and hybridization (Dunham and others, 2002; Warnock and Rasmussen, 2013; Kovach and others, 2016), with resident fish susceptible to the former throughout their complete life cycle. Given the number of threats, interactions among them, and how they can depend on the local context within which they occur, practitioners often face difficult decisions as to how best manage bull trout (for example, Tyre and others, 2011; Falke and others, 2015).

Here, we report on an analysis of threats and management scenarios for a population of bull trout in a headwater tributary in the Upper Klamath River Basin, south-central Oregon. In the Upper Klamath River Basin, existing habitat associations and overlapping distributions of bull trout and brook trout suggest the potential for negative effects of brook trout (Benjamin and others, 2016). In one stream within the Klamath River Basin, bull trout have responded positively to complete removal of brook trout with piscicide (Buktenica and others, 2013), providing further evidence of the potential for negative effects of brook trout. Complete removal of nonnative brook trout from other portions of the Klamath River Basin may be complicated by the cost of such operations and presence of other native taxa that could be harmed by application of piscicides (e.g., Finlayson and others, 2000). There is additional uncertainty regarding the effective prevention of re-establishment by brook trout following eradication and the probability of re-expression of migratory life histories by bull trout, which promotes population persistence. These examples represent some of the complexity and uncertainty of bull trout conservation in the Upper Klamath River Basin. 
To address these complexities, we applied the process of structured decision making (Gregory and others, 2012; Conroy and Peterson, 2013) to better understand the uncertainty of and to inform bull trout recovery decisions in the Klamath River Basin. We convened a stakeholder workshop to identify their fundamental objective for a local population of bull trout within the Sycan River Core Area. In this activity, stakeholders also identified means objectives (management alternatives intended to potentially address the fundamental objective). Finally, stakeholders identified preliminary models of factors that influence bull trout in the local population, as well as information to be used in parameterizing a model of population dynamics. With this information we, developed models to estimate bull trout population size and the consequences of alternative decisions, as well as to test assumptions about system behaviors (Conroy and Peterson, 2013).

\section{Study Area}

The Klamath River Basin is at the southern margin of the current range of bull trout (Dunham and others, 2008). The basin is recognized by U.S. Fish and Wildlife Service as one of six recovery units distributed across the range of the species in the continental United States (U.S. Fish and Wildlife Service, 2015a, 2015b). For management purposes, major tributaries within this basin are further classified into three core areas, including Upper Klamath Lake, Sycan River, and upper Sprague River (U.S. Fish and Wildlife Service, 2015a, 2015b; fig. 1).

The Sycan River Core Area consists of the Sycan River, Sycan Marsh, and their tributaries (fig. 1). On the eastern half of the core area is the Sycan River, which ranges in elevation from approximately $2,100 \mathrm{~m}$ at the headwaters to $1,500 \mathrm{~m}$ as it enters Sycan Marsh. On the western half of the catchment is Long Creek and its tributaries. Long Creek is the geographic extent of this study area and supports the last known population of bull trout in the Sycan River Core Area. Long Creek has a snow-melt dominated hydrograph, with peak flows in May and June and base flows starting in July.

Bull trout historically occurred throughout Long Creek and consisted of both resident and migratory individuals, with migrants achieving sizes up to $500 \mathrm{~mm}$ in length (Light and others, 1996, as cited in U.S. Fish and Wildlife Service, 2015b). Currently, bull trout are primarily restricted to the headwaters (that is, resident life-history), in part, owing to the presence of nonnative brook trout, which occupy most of Long Creek and its tributaries including Calahan Creek. Moreover, the migratory life history of bull trout in this system has been limited by degraded habitat conditions in the lower reaches of the migration corridor that seasonally affect connectivity between spawning grounds and juvenile rearing areas in the headwaters and adult rearing habitat in the Sycan Marsh. Under current conditions, the abundance of subadult and adult fish is less than 1,000 individuals (Buchanan and others, 1997), and the size of migrant adults typically does not exceed $300 \mathrm{~mm}$. In addition to bull trout, brook trout, and bull-brook trout hybrids, other fish present in Long Creek include Rainbow Trout (Oncorhyncus mykiss) and Speckled Dace (Rhinichthys osculus; Long and Bond, 1979). We consider the Long Creek system as representative of many bull trout management concerns - a headwater tributary (Long Creek) consisting of sympatric bull trout and brook trout populations, multiple tributaries with only brook trout (in this case, Calahan Creek), and lower reaches that are either degraded or fragmented. 

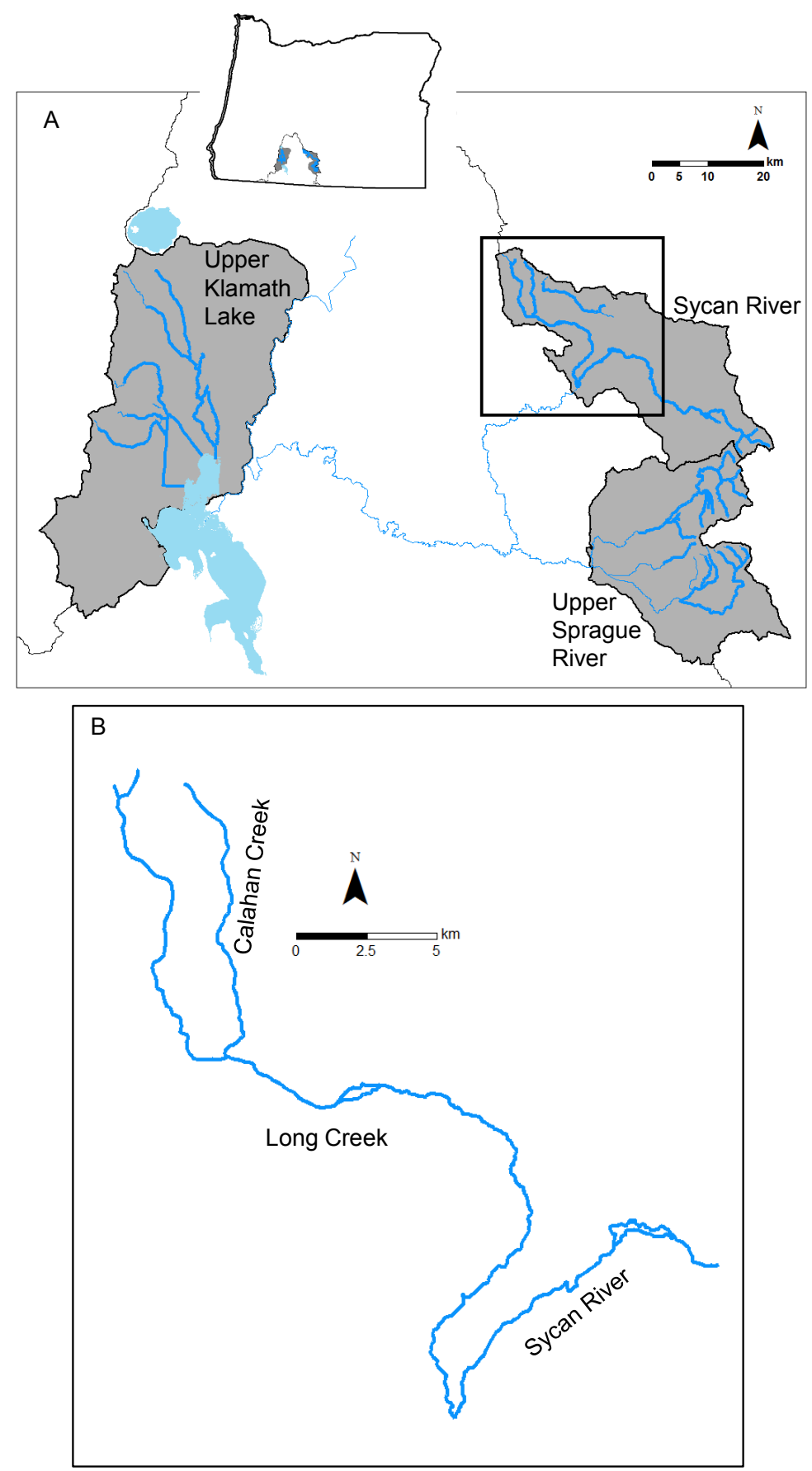

Figure 1. Schematics showing Upper Klamath River core areas (outlined with gray) with critical habitat highlighted in thick lines (panel A) and Long Creek watershed in the northern Sycan River Core Area considered in the modeling effort (panel B). 


\section{Methods}

\section{Decision Utility}

Any formal decision-making process requires a clear statement of objectives that specifies what management actions are attempting to achieve (Gregory and others, 2012; Conroy and Peterson, 2013). These objectives should be quantifiable to facilitate comparisons of the relative effectiveness of management actions and evaluations of the sensitivity of the estimates to assumptions. When there are two or more fundamental objectives, the quantifiable attributes for each objective are combined in a single number defined as the utility. To address these needs, we convened a stakeholder workshop in Klamath Falls, Oregon, on April 1, 2014, to elicit a host of responses, including (1) identification of a quantifiable objectives, (2) management alternatives, and (3) and effects on population dynamics of bull trout and brook trout in the Long Creek watershed. Refinement of management alternatives, model structure, and inputs were an iterative process, involving periodic feedback from stakeholders over the course of initial model development and revision. Stakeholders who agreed to participate included individuals representing the Oregon Department of Fish and Wildlife, U.S. Fish and Wildlife Service, U.S. Forest Service, National Park Service, The Nature Conservancy, and private landowners.

The problem statement developed by the stakeholders was as follows:

To achieve long term viability of Bull Trout populations in the Sycan Core Area by expanding and maintaining existing populations, establishing new populations, and improving stream and riparian habitats.

The geographic extent of the problem statement was further refined by the stakeholders to focus effort on a local population of bull trout in Long Creek, in the Sycan River Core Area of the Klamath River recovery unit (U.S. Fish and Wildlife Service, 2015a). The fundamental stakeholder objectives were to maximize the long-term persistence of bull trout and minimize the cost of management actions. The quantifiable attribute used to measure persistence was the number of adult bull trout (resident and migratory) in Long Creek and its tributaries in year 10 after the initiation of management actions, with the assumption that population size was directly related to long-term population viability. This time horizon was selected by the stakeholders because 10 years allowed for the completion of two life cycles for bull trout, and was an approximation of when subsequent management decisions would be made. The other fundamental objective was to minimize costs of management. Actual cost estimates were unavailable for many decisions alternatives. Therefore, we included qualitative cost estimates by asking the stakeholders to rank the cost for each alternative management action from 1 to 5, with 1 being the least expensive alternative and 5 being the most expensive alternative. For each decision, we summed the ranks for individual action, and then calculated the marginal gain (Conroy and Peterson, 2013) by dividing the summed ranks by the difference of implementing or not implementing a decision.

\section{Alternative Management Actions}

The stakeholders identified five potential management alternatives that could be implemented separately or in combination with each other (table 1) to achieve the fundamental objectives. Managers identified a 5-year time-step for implementing a management alternative.

The first management alternative was to institute a brook trout removal program through onepass electrofishing for the entire length of a tributary starting at the confluence. For example, if this action were to occur in Long Creek, the spatial extent upstream of the confluence with Calahan Creek. Based on stakeholder feedback, we assumed that logistics would limit electrofishing efforts, and removal would occur during either the first 3 years consecutively or every other year (that is, years 1, 3, and 5). Based on published brook trout capture efficiencies (Peterson, Fausch, and others, 2008), brook 
trout survival after each removal event was reduced by 65-75 percent, depending on life stage (table 2). bull trout, when present, also will be shocked during the brook trout removal, and subsequent mortality may occur. Thus, we assumed a 2.5-percent reduction in survival across most life stages of bull trout during the years in which electrofishing occurred, with the exception of eggs and migrants that would be absent during the time of sampling. We assumed a constant reduction in bull trout survival because it is difficult to identify the exact effects on each life stage. However, larger fish are more likely to be captured and experience handling mortality, whereas smaller fish are less likely to be captured and may experience mortality owing to injuries from repeat shocking.

The second management alternative included the installation of a barrier immediately upstream of a tributary mouth. The primary purpose of installing barriers is to prevent the upstream spread of nonnative fish like brook trout (Peterson, Rieman, and others, 2008; Fausch and others, 2009) to the tributary. We assumed that a barrier would be 100-percent effective at preventing brook trout immigration, but evaluated the sensitivity of the model to this assumption. The stakeholders also were interested in the effect that this management alternative would have on the migratory component of the bull trout population. We assumed that the barrier would allow bull trout migrants to move downstream, but would prevent all their movement upstream to spawning grounds (that is, no upstream migration existed).

The third management alternative was a complete eradication of brook trout, which could result from treating the stream with piscicide. For this action, we assumed a 100-percent removal of brook trout. We also assumed that, if present, bull trout could be removed without harm and transported to a holding facility (for example, following Buktenica and others, 2013). The application was similar to that of electrofishing removal upstream of the confluence of Long and Calahan Creeks.

The fourth management alternative was translocating subadult bull trout from one tributary to another tributary not occupied by bull trout (for example, from upper Long Creek to Calahan Creek). We assumed that all resident subadult bull trout were available for translocation, but only 50 percent of migratory subadults were available. The latter was because little is known of the distance subadults will migrate in the study area and this life stage might not be present in the collection area at the time of capture and transfer. Stakeholders identified a one-time mortality reduction of 5 percent that occurred for translocated subadult bull trout owing to the stress of capture, handling, transport, and release into a new environment. Additionally, we assumed that bull trout and brook trout that were electrofished but not captured received a penalty of 2.5 percent, which was consistent with the incidental electrofishing mortality rate during brook trout removal. We evaluated two options - translocating (1) 50 or (2) 100 subadult bull trout. If the number of subadults in the donor population was less than the number needed for the translocation, we assumed that all remaining resident subadults were translocated. Translocations occurred once in year 1 of the 5-year time-step.

In the last management alternative, we assumed that habitat conditions in a reach downstream from a headwater bull trout population (that is, areas occupied by the migratory life history) were improved. This alternative represented actions that promote connectivity between natal and migratory habitat or an improvement in conditions for adult migrant bull trout. We assumed that improving downstream conditions would increase the survival of migrant life stages by 10 percent. It is unlikely that benefits to migratory bull trout following improvements would be effective instantaneously. Thus, the increase in survival was not instantaneous, but gradual. We linearly increased the survival over the 5-year time-step (that is, 2 percent increase per year) to represent the cumulative effect of improvements. 
Table 1. Alternative management actions and combinations of actions evaluated in the decision model.

\begin{tabular}{lccccc}
\hline & \multicolumn{5}{c}{ Alternative management action } \\
\cline { 2 - 6 } Creek & $\begin{array}{c}\text { Brook trout } \\
\text { removal by } \\
\text { electrofishing }\end{array}$ & Barrier & $\begin{array}{c}\text { Brook trout } \\
\text { eradication }\end{array}$ & $\begin{array}{c}\text { Bull trout } \\
\text { translocation }{ }^{2}\end{array}$ & $\begin{array}{c}\text { Improve } \\
\text { downstream } \\
\text { conditions }\end{array}$ \\
\hline Long & $\mathrm{X}$ & - & - & - & - \\
Long & - & $\mathrm{X}$ & - & - & - \\
Long & $\mathrm{X}$ & $\mathrm{X}$ & - & - & - \\
Long & - & - & - & - & $\mathrm{X}$ \\
Long & - & - & $\mathrm{X}$ & - & - \\
Long & $\mathrm{X}$ & - & - & - & $\mathrm{X}$ \\
Long & - & - & $\mathrm{X}$ & - & $\mathrm{X}$ \\
Long & - & $\mathrm{X}$ & $\mathrm{X}$ & - & - \\
Calahan & $\mathrm{X}$ & - & - & $\mathrm{X}$ & - \\
Calahan & $\mathrm{X}$ & $\mathrm{X}$ & - & $\mathrm{X}$ & - \\
Calahan & - & - & $\mathrm{X}$ & $\mathrm{X}$ & - \\
\hline
\end{tabular}

${ }^{1}$ Removal options included every year for the first 3 years (years $1-3$ ) and every other year (years 1, 3, and 5).

${ }^{2}$ Translocation options included 50 and 100 subadult bull trout.

Table 2. Effects of management actions on demographic parameters for bull trout and brook trout.

\begin{tabular}{|c|c|c|c|c|c|c|}
\hline \multirow[b]{2}{*}{$\begin{array}{l}\text { Trout } \\
\text { species }\end{array}$} & \multirow[b]{2}{*}{ Parameter } & \multicolumn{5}{|c|}{ Management alternative action } \\
\hline & & $\begin{array}{l}\text { Brook trout } \\
\text { removal by } \\
\text { electrofish } \\
\text { (percentage) }\end{array}$ & $\begin{array}{c}\text { Barrier } \\
\text { (percentage) }\end{array}$ & $\begin{array}{l}\text { Brook trout } \\
\text { eradication } \\
\text { (percentage) }\end{array}$ & $\begin{array}{l}\text { Bull trout } \\
\text { translocation } \\
\text { (percentage) }\end{array}$ & $\begin{array}{c}\text { Improve } \\
\text { downstream } \\
\text { conditions }^{2} \\
\text { (percentage) }\end{array}$ \\
\hline Bull & Juvenile survival & -2.5 & - & - & -2.5 & - \\
\hline Bull & Resident subadult survival & -2.5 & - & - & -5 & - \\
\hline Bull & Resident adult survival & -2.5 & - & - & -2.5 & - \\
\hline Bull & Migrant subadult survival & -2.5 & -100 & - & -5 & 10 \\
\hline Bull & Migrant adult survival & - & -100 & - & - & 10 \\
\hline Brook & Juvenile survival & -65 & - & -100 & -2.5 & - \\
\hline Brook & Subadult survival & -71 & - & -100 & -2.5 & - \\
\hline Brook & Small adult survival & -75 & - & -100 & -2.5 & - \\
\hline Brook & Large adult survival & -75 & - & -100 & -2.5 & - \\
\hline
\end{tabular}

${ }^{1}$ Effects of electrofishing on survival occur only during the years in which electrofishing occurs.

${ }^{2}$ Changes in survival occur linearly over a 5 -year period. 


\section{Model Overview}

To evaluate the proposed management actions, we created a decision model consisting of management alternatives, stakeholder objectives, and system dynamics. The dynamics of native bull trout and nonnative brook trout were modeled using a deterministic, staged-based Lefkovitch matrix model (Lefkovitch, 1965). The model allows the two Salvelinus species to occur either in sympatry or allopatry. For bull trout, we considered two life history tactics (resident and migratory); hence the population model consisted of six life-history stages - (1) eggs, (2) juveniles, (3) resident subadults, (4) resident adults, (5) migratory subadults, and (6) migratory adults (fig. 2A). The life history tactic of the subadult identifies the tactic for the adult stages. That is, migrant subadults always transition to migrant adults and resident subadults always transition to resident adults. Brook trout typically only display a resident life history tactic in their nonnative range (Dunham and others, 2002; Fausch, 2008). Therefore, the brook trout population dynamics model included five life stages- (1) eggs, (2) juveniles, (3) resident subadults,(4) resident small adults, and (5) resident large adults (fig. 2B). Both population models operate on an annual time step and begin with a specified number of individuals for each species in each stage. Each simulated year begins with reproduction. For each species, we assumed a 50/50 sex ratio and that the number of eggs produced was the product of the number of reproductively mature adult females by the stage-specific fecundity summed across stages. Individuals in each stage then were promoted to the next stage using survival and stage transition rates that varied according to management actions and hypothesized dynamics. Management actions were implemented within the first 5 years of a simulation, and population dynamics continued for 5 additional years with no additional management interventions. The number of adult bull trout in year 10 represented the final output.

Initially, we parameterized the model using demographic values (for example, survival, fecundity) for each species and stage based on published demographic information (table 3).

Stakeholder feedback indicated that the values we used needed to be adjusted for use in the Long Creek decision. Therefore, we modified several aspects of the model. First, we defined a migratory bull trout as an individual that rears downstream past the confluence of Long Creek and Calahan Creek. The stakeholders commented that bull trout in Long Creek at present do not exceed $250 \mathrm{~mm}$ in length (but see Light and others, 1996), so large adult resident and migrant bull trout life stages were not considered in the model. The stakeholders also suggested that the brook trout population was stable or growing and that the bull trout population was declining. Thus, brook trout were assumed to have a stable population growth rate $(\lambda=1)$, whereas bull trout were assumed to have a declining population $(\lambda=0.9)$. Simulated management decisions potentially will change the growth rate following implementation. In the sympatric stream (that is, Long Creek), stakeholders also thought that the population ratio of brook trout to bull trout was 25:1. Starting values for demographic parameters (for example, survival, fecundity) for each species and stage were assigned using life history tactics (that is, resident or migratory) and size based on stakeholder feedback and literature values (table 3 ). These values then were adjusted to match the specified species ratios, population growth rates, and hypothesized population dynamics using optimization techniques (see section, "Population Dynamic Hypotheses"). Adult bull trout may skip a breeding season owing to density dependence (Johnston and others, 2007); however, we did not account for this because it is a strategy that is more prominent in males, and only in females when their abundance exceeds 1,000 individuals (Johnston and Post, 2009), which is unlikely under current conditions in Long Creek. 


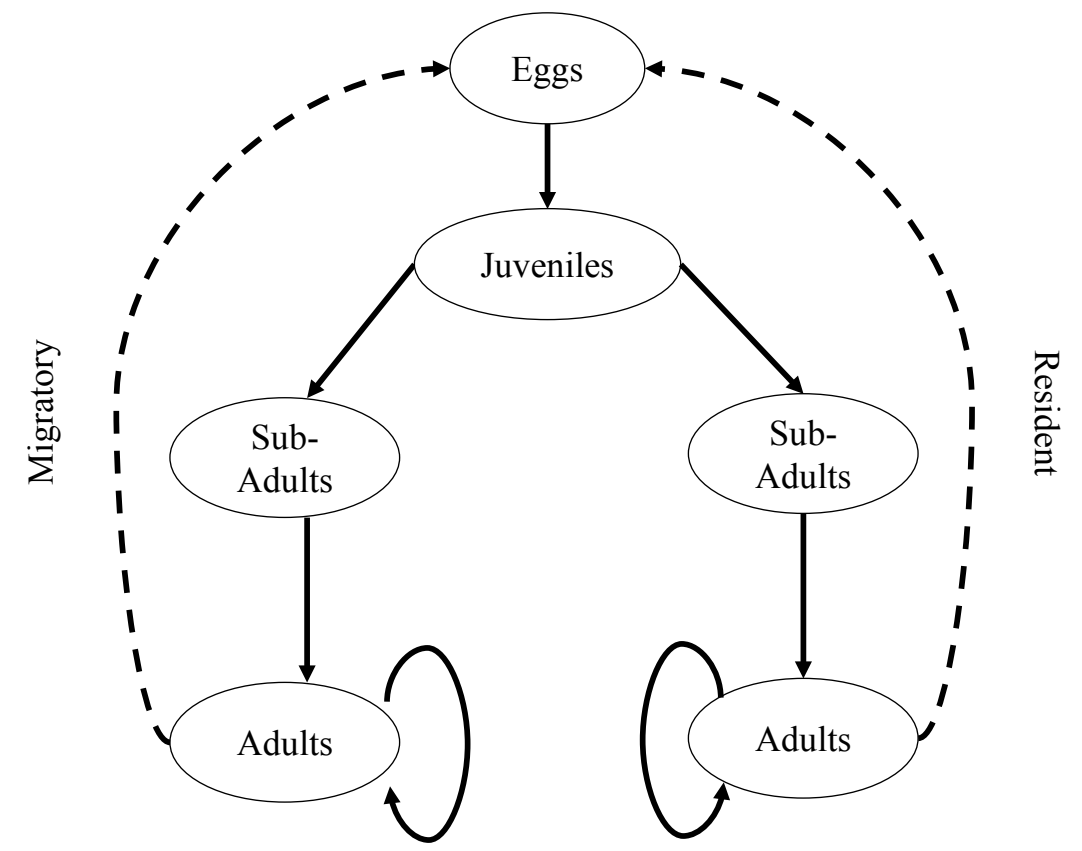

\section{B. Brook trout life cycle}

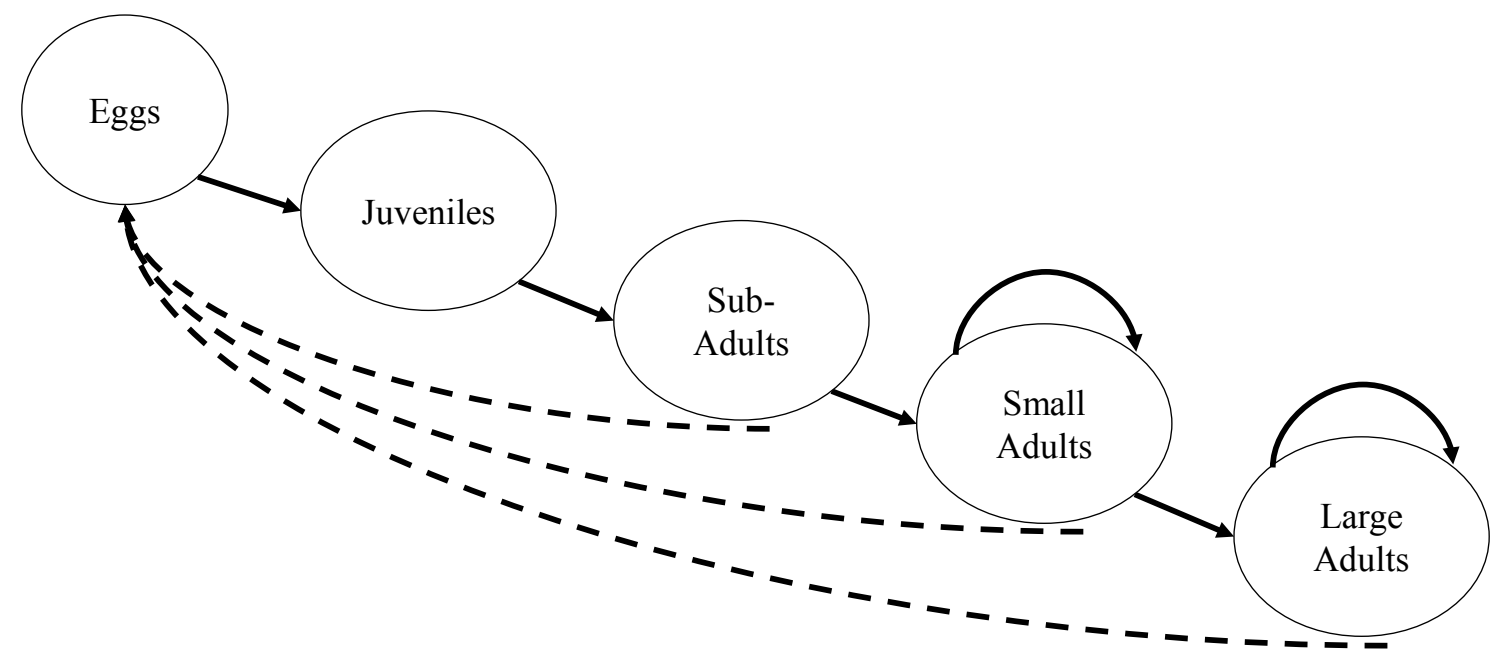

Figure 2. Diagram showing life cycle for bull trout $(A)$ and brook trout $(B)$. Solid lines denote transitions from one stage to the next, and dotted lines denote the reproductive output. 
Table 3. Demographic parameter values used for bull trout and brook trout matrix models.

[Table includes starting values that were identified by stakeholders and literature, source, optimized values to ensure target population growth rates, and the range of values used in sensitivity analyses. Abbreviation and symbol: mm, millimeter; >, greater than]

\begin{tabular}{|c|c|c|c|c|c|}
\hline \multirow{2}{*}{$\begin{array}{l}\text { Trout } \\
\text { species }\end{array}$} & \multirow{2}{*}{ Parameter } & \multicolumn{2}{|c|}{ Starting value } & \multirow{2}{*}{ Optimized value ${ }^{2}$} & \multirow{2}{*}{ Range } \\
\hline & & Value & Source ${ }^{1}$ & & \\
\hline Bull & Egg survival & 0.06 & - & 0.08 & $0.04-0.12$ \\
\hline Bull & Juvenile survival & 0.2 & 1 & Function & - \\
\hline Bull & Resident subadult (100-139 mm) survival & 0.35 & 2 & 0.33 & $0.16-0.49$ \\
\hline Bull & Resident adult (140-170 mm) survival & 0.4 & 2 & 0.44 & $0.22-0.67$ \\
\hline Bull & Migrant subadult (100-170 mm) survival & 0.4 & 2 & 0.49 & $0.25-0.74$ \\
\hline Bull & Migrant adult (171-240 mm) survival & 0.6 & 2 & 0.74 & $0.37-1.0$ \\
\hline Bull & Proportion juveniles becoming migrants ${ }^{3}$ & 0.2 & 2 & 0.18 & $0.09-0.26$ \\
\hline Bull & Number of years as subadult & 3 & - & - & $1.5-4.5$ \\
\hline Bull & Exponential migrant rate parameter ${ }^{4}$ & - & - & $2.27 \times 10^{-5}$ & - \\
\hline Bull & Resident adult fecundity & 200 & 1,2 & - & $100-300$ \\
\hline Bull & Migrant adult fecundity & 400 & 1,2 & - & $200-600$ \\
\hline Bull & Sex ratio $^{5}$ & 0.5 & - & - & $0.25-0.75$ \\
\hline Brook & Egg survival & 0.061 & 3 & 0.08 & $0.04-0.19$ \\
\hline Brook & Juvenile survival & 0.323 & 3 & Function & \\
\hline Brook & Subadult (100-139 mm) survival & 0.383 & 3 & 0.39 & $0.20-0.59$ \\
\hline Brook & Small adult (140-170 mm) survival & 0.371 & 3 & 0.48 & $0.24-0.71$ \\
\hline Brook & Large adult (>170 mm) survival & 0.371 & 3 & 0.31 & $0.15-0.46$ \\
\hline Brook & Subadult fecundity & 25 & 3 & - & $13-37$ \\
\hline Brook & Small adult fecundity & 234 & 3 & - & $117-351$ \\
\hline Brook & Large adult fecundity & 616 & 3 & - & $308-924$ \\
\hline Brook & Subadult maturity rate & 0.25 & 3 & - & $0.13-0.38$ \\
\hline Brook & Small adult maturity rate & 0.75 & 3 & - & $0.38-1.0$ \\
\hline Brook & Large adult maturity rate & 1 & 3 & - & $0.5-1.0$ \\
\hline Brook & Sex ratio $^{5}$ & 0.5 & - & - & $0.25-0.75$ \\
\hline
\end{tabular}

${ }^{1} 1=$ Bowerman, 2013; 2=Al-Chokhachy and Budy, 2008; 3=Peterson, Fausch, and others, 2008; all values were confirmed by stakeholders.

${ }^{2}$ Dashes mean starting values were used.

${ }^{3}$ Parameter only used for adult hypothesis a (AdultHa).

${ }^{4}$ Parameter only used for adult hypotheses $\mathrm{b}$ and $\mathrm{c}$ (AdultHb and AdultHc).

${ }^{5}$ Assumed; same ratio for all stages. 


\section{Population Dynamic Hypotheses}

Assumptions about the nature of interaction between brook trout and bull trout and the mechanisms influencing bull trout life history tactics have the potential to influence decision making. To incorporate this source of uncertainty in the decision model, we developed alternative models representing hypothesized system dynamics. For species interactions, we considered two hypotheses; juvenile density dependence is intraspecific (JuvHa) or interspecific (JuvHb). The JuvHa hypothesis assumed that juvenile Brook and bull trout do not directly interact, and, thus, the effect of density dependence on juvenile survival $\left(S_{j}\right)$ is intraspecific. To account for the effect of density dependence on survival, we used the density-dependent survival function from Lee and Rieman (1997):

$$
S_{j i}=S_{\max , i} *\left(1-e^{-K_{\text {egg }, i} /\left(S_{\max , i} * \operatorname{\Sigma egg} S_{i}\right)}\right),
$$

where
$S_{j} \quad$ is the egg to juvenile survival for species $i$,
$S_{\max } \quad$ is the maximum egg to juvenile survival,
$K_{\text {egg }} \quad$ is the carrying capacity for eggs of species $i$, and
eggs is the total number of eggs produced by species $i$.

However, brook trout can restrict bull trout to headwater sections in the Klamath River Basin (Benjamin and others, 2016), suggesting that competition and lab experiments have shown that brook trout can out-compete with bull trout for available resources (McMahon and others, 2007). Therefore, as an alternative, we hypothesized that carrying capacity of juveniles between the two species was shared, and that density-dependent effects on juvenile survival are a function of both species. We used the same equation as JuvHa, except that eggs was the cumulative number of eggs for both species instead of from a single species.

To incorporate the uncertainty regarding the mechanisms influencing bull trout life history tactics, we considered three sets of hypotheses based on stakeholder input. First, we assumed that the proportion of juveniles that become migrants is a constant proportion (0.2) every year (AdultHa). Density dependence has been suggested as a mechanism influencing bull trout life history tactics (Chapman and others, 2011). Thus, we used two approaches to model the proportion of juveniles that become migrants to be a function of trout density. First, we hypothesized (AdultHb) that the proportion of migrants $\left(p_{m i g}\right)$ is dependent on the total number of subadult and adult bull trout (adults):

$$
p_{\text {mig }}=\left(1-e^{\left(\alpha^{*} \text { adults }\right)}\right)
$$

where

$$
\alpha \quad \text { is exponential rate parameter. }
$$

As a second alternative hypothesis (AdultHc), the proportion of juvenile bull trout to become migratory was hypothesized to be a function of both resident bull trout and brook trout density. We used the same equation as AdultHb, but for adults we used the total number of resident subadult and adult bull trout and brook trout. 


\section{Parameter Estimate Calibration}

We had no a priori assumption that one or more of the alternative hypotheses regarding the effect of brook trout on sympatric bull trout populations was more likely than the others. We reasoned that all hypotheses are equally likely and, more importantly, that they theoretically should be able to result in the observed starting states of the populations (at $\mathrm{t}=0)$. For simplicity, we assumed that the initial population growth rates $\left(\lambda\right.$ at $t_{0}$ ) were equal to 0.9 for bull trout and 1.0 for brook trout. Using these growth rates and demographic parameter estimates from stakeholder feedback and published studies as bounds, we calibrated each alternative model with a two-step procedure (table 1).

For the first step, we used heuristic optimization to estimate stage-specific survival for each population as well as migratory rates for the initial bull trout population (table 3 ). This was necessary to ensure that modeling results were directly comparable regardless of the hypothesized dynamics. The parameter estimation was accomplished using a genetic algorithm (Mebane and Sekhon, 2011), during which all the demographic parameters were estimated simultaneously until the population growth rates achieved the target values ( 0.9 for bull trout and 1.0 for brook trout). The stage-based survival rates were bound within 20 percent of their reported values to ensure that the optimized values were within the ranges of those reported in the literature (Al-Chokhachy and Budy, 2008; Peterson, Fausch, and others, 2008; Bowerman, 2013).

Once the demographic parameters were obtained, we estimated parameters $S_{\max }$ and eggs (eq. 1) for the density-dependent juvenile survival hypothesis (JuvHa) with Nealder-Mead optimization (Nelder and Mead, 1965) using the optim function in the statistical program $R v 3.1$ (R Core Team, 2016). The juvenile survival rates, $S_{j}$, that were estimated in step 1 were used as the target values during the optimization. The number of eggs in the system, eggs, was fixed and calculated using expected (mean) parameter values at the initial population size. Parameters were estimated for each individual population. This process was repeated using the equation for the juvenile hypothesis (JuvHb), but using the cumulative number of eggs in each tributary. Lastly, the parameter $\alpha$ (eq. 2) in adult hypothesis (AdultHa and AdultHb) was similarly estimated using a Nealder-Mead optimization. The total number of adult bull trout, adults, was fixed using the initial number of adult trout, and the value of $p_{\text {mig }}$ was taken from the values estimated in step 1.

\section{Sensitivity Analysis}

To identify the parameters that had the greatest effect on the number of adult bull trout at year 10, we performed one-way and two-way sensitivity analyses. For each sensitivity analyses, we varied parameters by \pm 50 percent of the mean estimate (table 3 ). During one-way sensitivity analysis, each input or parameter was changed individually across its range, holding the remaining inputs and parameters at their mean values (table 3 ). The two-way sensitivity analysis was similar to one-way analysis, but with values from two model parameters being varied simultaneously while the other model parameters were held at mean values. All sensitivity analyses were reported using the estimates from alternative population dynamic hypotheses averaged across models. 
To identify the model components that had the greatest effect on the optimal decision (in this case, the decision maximizing number of adult bull trout in the Long Creek population over a 10-year period), we performed one- and two-way response profile sensitivity analyses. Here, the individual model inputs and model parameters (or pairs for two-way analysis) were varied by \pm 50 percent of their means while keeping all other parameters at their mean values (table 3 ). Unlike one-way sensitivity analysis, the optimal decision was recorded for each combination. These values then were plotted to examine how optimal decisions change over the range of values for the model component. Model components for which decisions changed several times across a range of plausible parameter values were considered influential or key uncertainties.

Stakeholders were interested in evaluating how the magnitude of change in downstream conditions, the efficiency of electrofishing removal of brook trout, the effect of passing bull trout upstream of a barrier, and brook trout immigration from downstream affected decision making. Therefore, we conducted an additional response profile sensitivity analysis to address these questions. For decisions that included adding a barrier, up to 50 migrant bull trout adults per year were added upstream to the spawning population under the assumption that this would mimic efforts of the manager to place migratory adults upstream of the barrier prior to spawning. Because we did not include the potential for brook trout to immigrate to upper Long Creek or Calahan Creek from downstream locations, we ran the sensitivity of decisions under a range (1-200 fish per year) of adult brook trout immigrating. This included the migration rate of 100 adult brook trout per year (Peterson and Fausch, 2003).

We used cost ranks in place of actual management costs to calculate the utility because actual cost estimates were not available for most of the decision alternatives. The differences in ranks may not faithfully approximate the actual cost differences among alternatives. For example, the use of rankings assumed that the difference in actual monetary costs between the first- and second-ranked cost actions were equal to the difference in actual costs between fourth- and fifth-ranked actions. Therefore, a third sensitivity analysis was used to evaluate the sensitivity of decisions to the cost rankings elicited from the stakeholders. Here, we used indifference curves to evaluate how the optimal decision varied across a range of values defining the number of cost units between adjacent ranks. Specifically, we estimated the scaled cost of a decision as:

$$
C_{a^{\prime}}=C_{j}{ }^{*} w
$$

where

$$
\begin{array}{ll}
C_{a^{\prime}} & \text { is the scaled cost rank of decision } a \\
C_{j} & \text { is the cost rank of the decision under comparison, and } \\
w & \text { is the weighted value for the decision under comparison that was varied from } 20 \text { to } \\
& 160 \text { percent. }
\end{array}
$$

For each decision, the utilities were plotted across the range of weights, with the optimal decision considered the one with the greatest utility. The value of $w$, where two decision-specific lines cross, indicates that the utilities of the corresponding decision are equal and decision makers are indifferent to the decisions. 


\section{Results}

\section{Optimal Decision}

Controlling brook trout and improving conditions downstream had the greatest effect on the number of adult bull trout at year 10 and we estimated this combination of management actions would result in approximately 50 more adults, on average, compared to not implementing an action (fig. 3). The estimated abundance for decisions that included improving downstream conditions was consistently among the highest, whereas the estimated abundance for decisions that included installing a barrier was consistently among the lowest. Controlling brook trout through complete eradication or electrofishing removal was most optimal when brook trout and bull trout were in sympatry. However, when brook trout were in allopatry, the results were minimal. Similarly, translocation of bull trout to a tributary had little to no effect on the estimated adult abundance.

We received cost ranks from two stakeholders (table 4) and used these to calculate the marginal gain of each decision alternative (that is, the utility). When costs were considered, on average, the optimal decision became electrofishing removal of brook trout from Long Creek (fig. 3) followed by electrofishing removal coupled with improving downstream conditions.

Table 4. Ranked cost from least (1) to most (5) expensive for each alternative management action.

\begin{tabular}{lc}
\hline \multicolumn{1}{c}{ Alternative management action } & Ranked cost \\
\hline Bull trout translocation & 1 \\
Brook trout removal by electrofishing & 2 \\
Barrier & 3 \\
Brook trout eradication & 4 \\
Improve downstream conditions & 5 \\
\hline
\end{tabular}




\begin{tabular}{|c|c|c|c|c|c|}
\hline \multirow[b]{2}{*}{ Creek } & \multicolumn{5}{|c|}{ Management actions } \\
\hline & $E$ & $\mathrm{R}$ & DS & $\mathrm{TL}$ & $B$ \\
\hline $\mathrm{L}$ & $\mathrm{X}$ & & $\mathrm{x}$ & & \\
\hline$L$ & & $X_{s}$ & $\mathrm{X}$ & & \\
\hline L & & $\mathrm{X}_{\mathrm{a}}$ & $\mathrm{X}$ & & \\
\hline$L$ & $X$ & & & & \\
\hline L & & $X_{s}$ & & & \\
\hline \multirow[t]{2}{*}{ L } & & $\mathrm{X}_{\mathrm{a}}$ & & & \\
\hline & & & $\mathrm{X}$ & & \\
\hline C & $\mathrm{X}$ & & & $X_{100}$ & \\
\hline C & & $X_{s}$ & & $X_{100}$ & \\
\hline C & & $X_{a}$ & & $X_{100}$ & \\
\hline C & $\mathrm{X}$ & & & $X_{50}$ & \\
\hline C & & $X_{s}$ & & $X_{50}$ & \\
\hline C & & $X_{a}$ & & $X_{50}$ & \\
\hline C & & $X_{s}$ & & $X_{50}$ & $x$ \\
\hline C & & $\mathrm{X}_{\mathrm{a}}$ & & $X_{50}$ & $x$ \\
\hline C & & $X_{s}$ & & $X_{100}$ & $x$ \\
\hline C & & $\mathrm{X}_{\mathrm{a}}$ & & $X_{100}$ & $x$ \\
\hline $\mathrm{L}$ & $\mathrm{X}$ & & & & $\mathrm{x}$ \\
\hline L & & $X_{s}$ & & & $x$ \\
\hline L & & $\mathrm{X}_{\mathrm{a}}$ & & & $x$ \\
\hline $\mathrm{L}$ & & & & & $\mathrm{X}$ \\
\hline
\end{tabular}

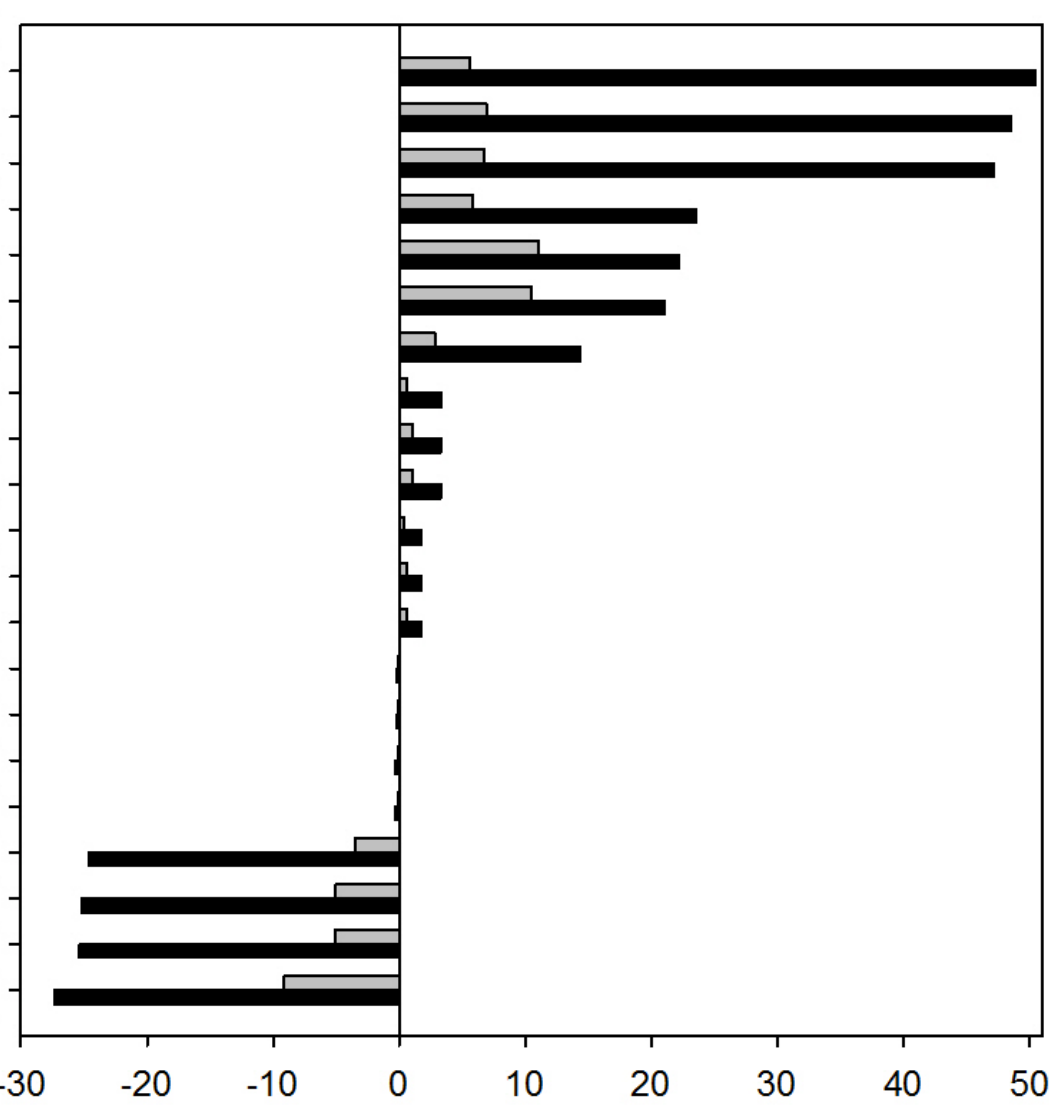

Difference in number of adult Bull Trout or marginal gain

Figure 3. Graph showing difference in the number of adult bull trout (resident and migrant; black bar) or the marginal gain or loss (gray bar) for each decision relative to not implementing a decision. Values presented are for the average response across all population dynamic assumptions. L, Long Creek; C, Calahan Creek; E, brook trout eradication; $R$, brook trout removal through electrofishing in sequential (s) or alternative (a) years; DS, improve downstream conditions; TL, translocate 100 or 50 subadult bull trout; and B, barrier. 


\section{Sensitivity Analyses}

The optimal decision also was strongly influenced by the alternative model of bull trout population dynamics (fig. 4). Models that included an interaction between bull trout and brook trout estimated greater increases in adult population size in response to management actions compared to those with no interaction. Similarly, the model assuming that a constant proportion of juveniles become migrants predicted greater increases in adult population size at year 10 compared to models where the proportion was a function of density. The most robust decision was improving downstream conditions, which was indicated by the tight grouping of estimates under the alternative models and with consistent increase in adult bull trout (14 individuals, on average after 10 years). The translocation decision also was robust to assumptions of alternative bull trout population dynamics, but had minimal effect after a 10 -year period. Similarly, regardless of population dynamics assumptions, models where installing a barrier were considered had no or negative effects on adult bull trout.

On average, the number of adult bull trout simulated in the model was most influenced by the survival of multiple life stages, and was least sensitive to brook trout demographic parameters (fig. 5). The most sensitive parameter was, overwhelmingly, the survival of migrant adults. Other bull trout demographic parameters that were influential were the survival of resident adults and subadults, juvenile survival, the number of years resident subadults spend in the stage, egg survival, and the sex ratio of migrant adults. Among the bull trout demographic parameters, the least sensitive variables were the proportion of juveniles becoming migrants, resident sex ratio, and the fecundity of resident adults. Although the number of adult bull trout was not highly sensitive to brook trout demographic parameters, the survival of subadults, small adults, juveniles, and eggs were more influential than other brook trout parameters.

A one-way response profile sensitivity plot was created for a range of values for each of the bull trout and brook trout demographic parameters, for a total of 27 plots. We present four profiles that represent the most influential components, as well as the range of responses simulated (fig. 6). One-way response profile sensitivity analysis suggested that the optimal decision of eradicating brook trout from Long Creek and improving downstream conditions was relatively insensitive to changes in model parameters. This decision remained optimal regardless of the demographic parameters and their values for bull trout or brook trout. However, some decisions did have estimates of the number of adult bull trout at year 10 that were close to the optimal decision, depending on the model parameter and its value. For example, when coupled with improving downstream conditions, controlling brook trout either through electrofishing or complete eradication yielded a similar modeled result in the increased abundance of bull trout. 


\begin{tabular}{|c|c|c|c|c|c|}
\hline \multirow[b]{2}{*}{ Creek } & \multicolumn{5}{|c|}{ Management actions } \\
\hline & $E$ & $\mathrm{R}$ & DS & $\mathrm{TL}$ & $B$ \\
\hline $\mathrm{L}$ & $\mathrm{X}$ & & $\mathrm{X}$ & & \\
\hline L & & $X_{s}$ & $x$ & & \\
\hline L & & $X_{a}$ & $\mathrm{X}$ & & \\
\hline $\mathrm{L}$ & $\mathrm{X}$ & & & & \\
\hline L & & $X_{s}$ & & & \\
\hline \multirow[t]{2}{*}{$\mathrm{L}$} & & $\mathrm{X}_{\mathrm{a}}$ & & & \\
\hline & & & $X$ & & \\
\hline $\mathrm{C}$ & $X$ & & & $X_{100}$ & \\
\hline C & & $X_{s}$ & & $X_{100}$ & \\
\hline C & & $X_{a}$ & & $X_{100}$ & \\
\hline C & $\mathrm{X}$ & & & $X_{50}$ & \\
\hline C & & $X_{s}$ & & $X_{50}$ & \\
\hline $\mathrm{C}$ & & $\mathrm{X}_{\mathrm{a}}$ & & $X_{50}$ & \\
\hline $\mathrm{C}$ & & $X_{s}$ & & $X_{50}$ & $x$ \\
\hline C & & $X_{a}$ & & $X_{50}$ & $x$ \\
\hline C & & $X_{s}$ & & $X_{100}$ & $x$ \\
\hline C & & $X_{a}$ & & $X_{100}$ & $\mathrm{x}$ \\
\hline $\mathrm{L}$ & $\mathrm{X}$ & & & & $\mathrm{x}$ \\
\hline $\mathrm{L}$ & & $X_{s}$ & & & $\mathrm{x}$ \\
\hline L & & $\mathrm{X}_{\mathrm{a}}$ & & & $\mathrm{x}$ \\
\hline $\mathrm{L}$ & & & & & $\mathrm{x}$ \\
\hline
\end{tabular}

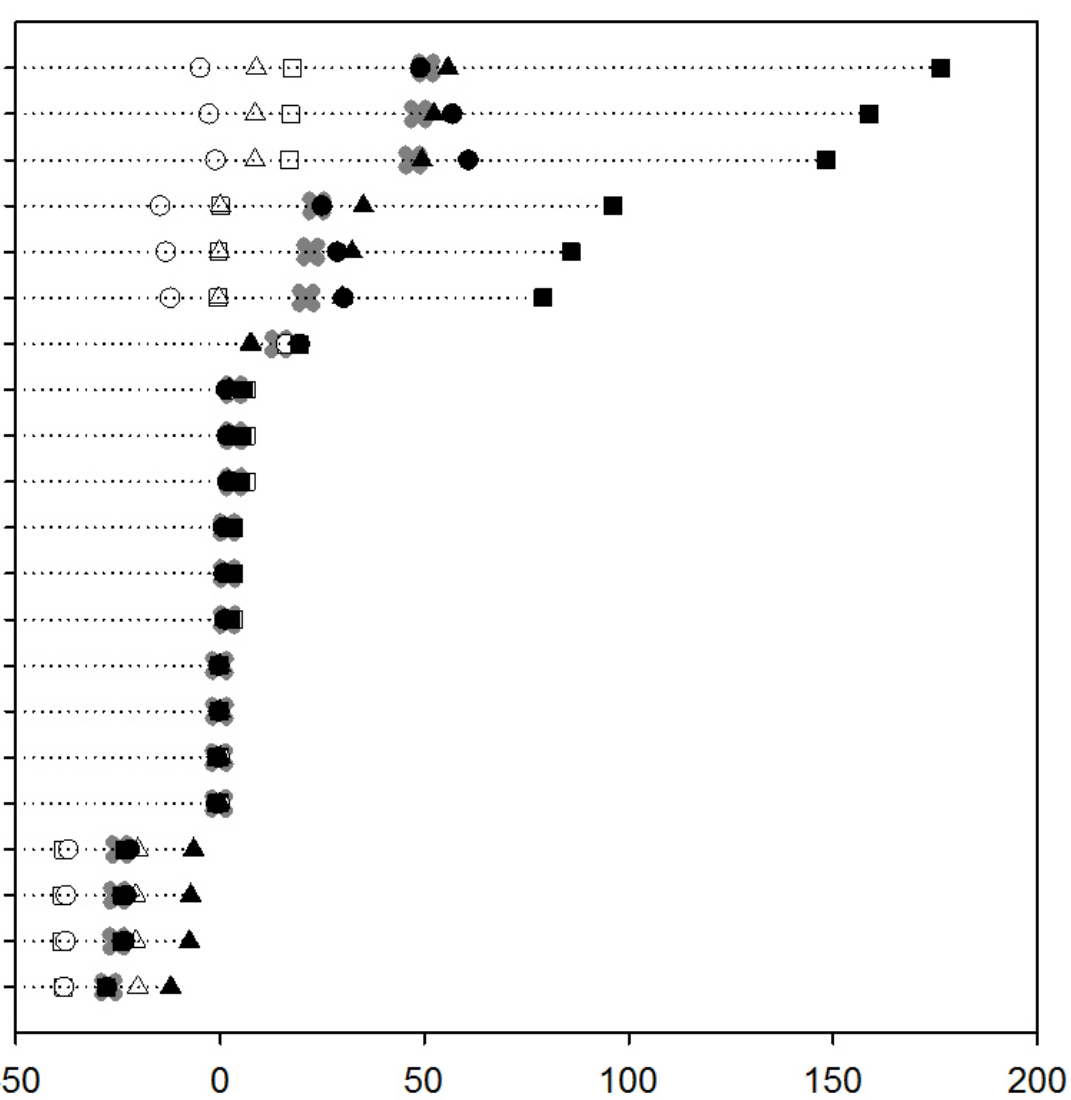

Difference in number of adult bull trout

Figure 4. Graph showing difference in the number of adult bull trout (resident and migrant) for each decision relative to a no-action decision. Modeled outcomes (predictions) are specific to each alternative (as opposed to overall averages represented in fig. 3). Open (no competition) and closed (with competition) symbols represent predictions under alternative models of competition between juvenile brook trout and bull trout. Predictions under alternative models of migration life history mechanisms are represented by different symbols: constant proportion (squares), a function of resident bull trout abundance (triangles), or a function of resident bull trout and brook trout abundance (circles). The gray $\mathrm{X}$ represents the average response across alternative models. L, Long Creek; C, Calahan Creek; $E$, brook trout eradication; $R$, brook trout removal through electrofishing in sequential (s) or alternative (a) years; DS, improve downstream conditions; TL, translocate 100 or 50 subadult bull trout; and B, barrier. 


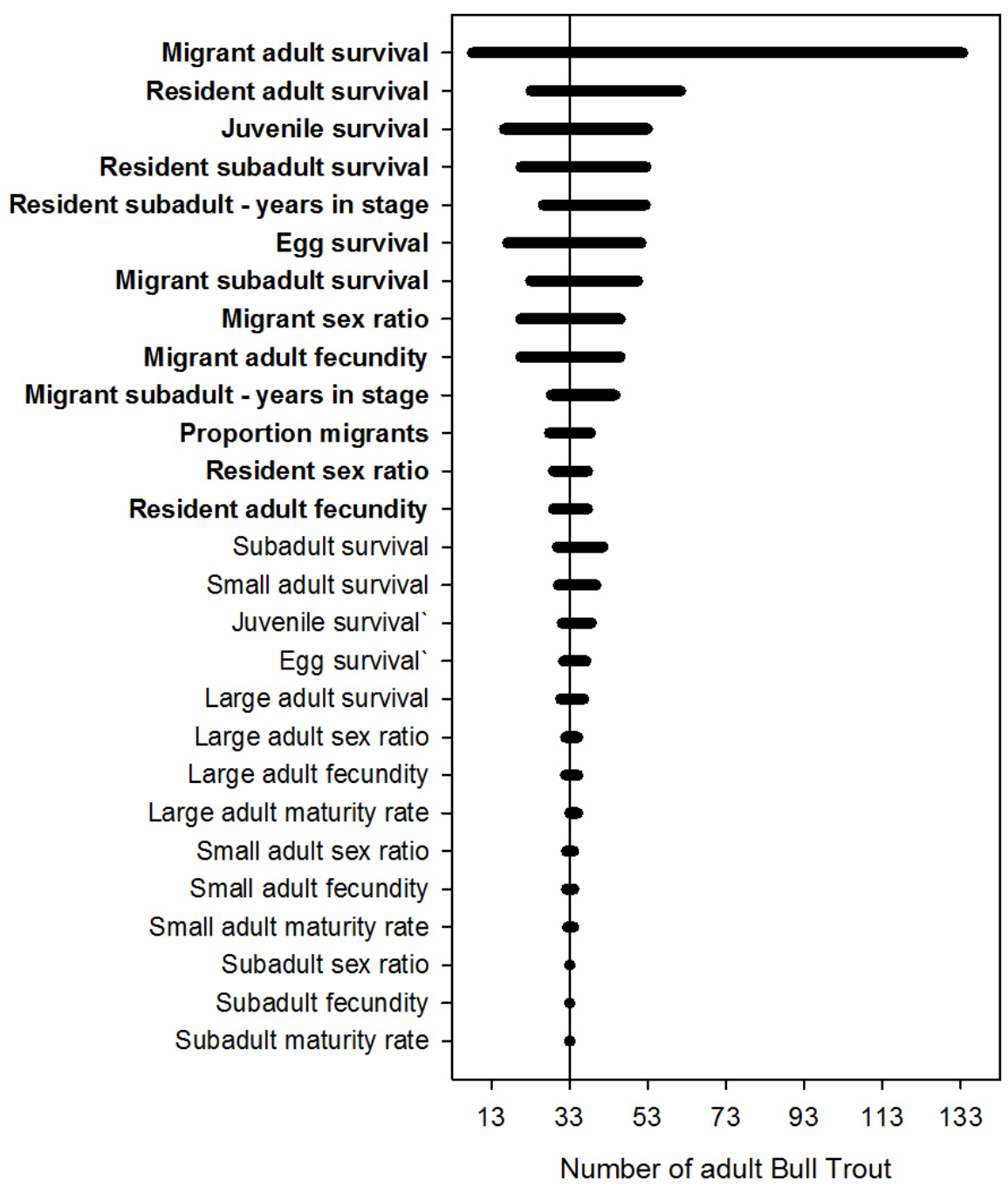

Figure 5. Graph showing changes in number of adult bull trout at year 10 based on one-way sensitivity analysis. Values are averaged across the different population dynamic hypotheses. On y-axis, text in bold indicates bull trout demographic parameters, and text not in bold indicates brook trout demographic parameters. 


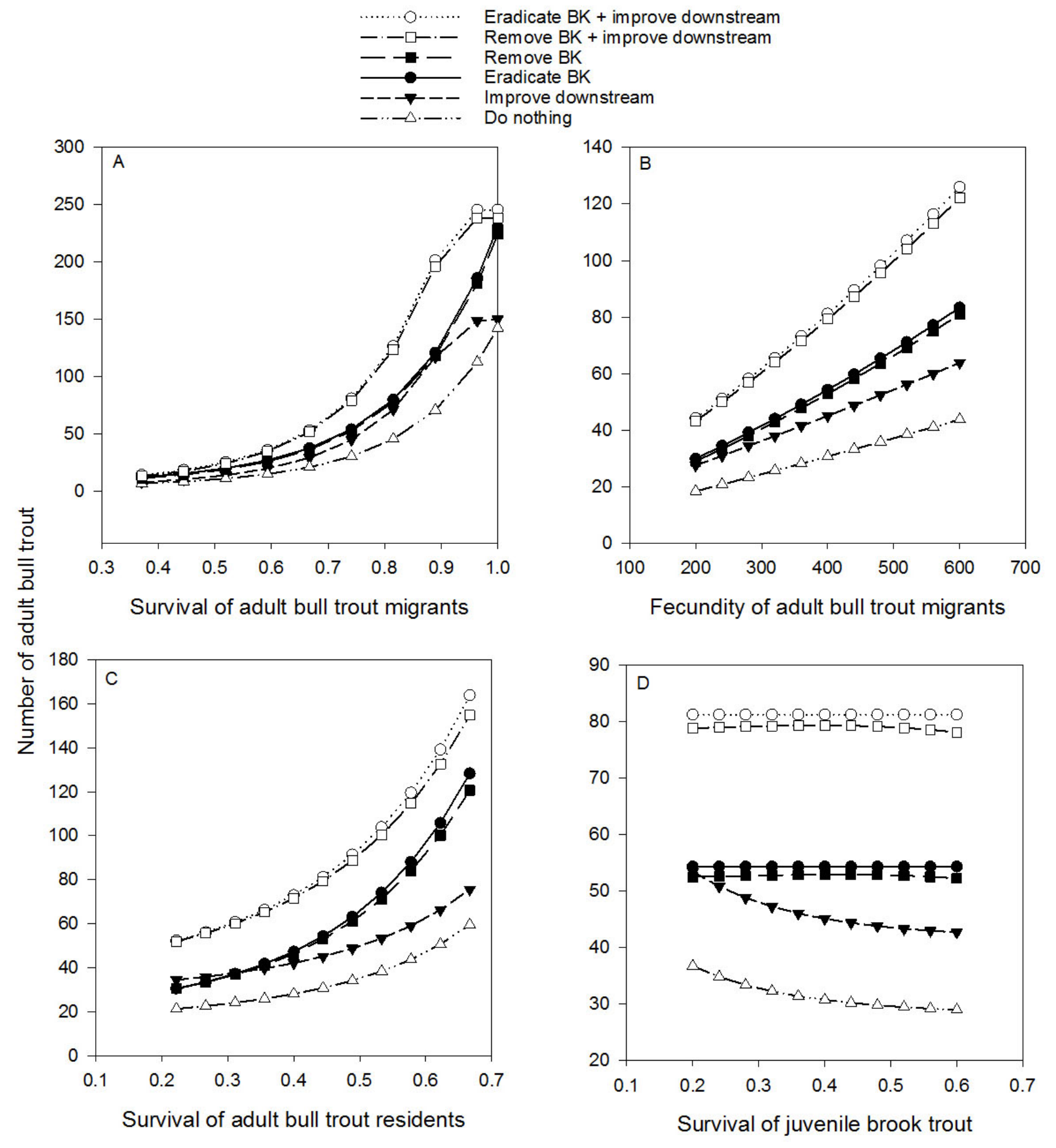

Figure 6. One-way response profiles showing top five decisions and a do nothing scenario under a range of values for (A) survival of adult bull trout migrants, (B) fecundity of adult bull trout migrants, (C) survival of adult bull trout residents, and (D) survival of juvenile brook trout. Number of adult bull trout are averaged across the different population dynamic hypotheses. Because of the similarity between removing brook trout through electrofishing over consecutive years and alternate years, we only present the results from the consecutive year alternative. Values are averaged across the different population dynamic hypotheses. 
The two-way sensitivity analysis averaged across alternative model (hypotheses) produced 378 combinations of model components and corresponding graphs, of which we present four that represent some of the most influential parameters and the variability of patterns observed (fig. 7). The two-way sensitivity analysis indicated that the number of adult bull trout at year 10 was sensitive to demographic parameters similar to those in the one-way sensitivity analysis. That is, when plotted against other demographic parameters, the estimated abundance was strongly influenced by the survival of adult migrant bull trout. We provide two examples, plotted against survival of resident adult bull trout and subadult brook trout. A comparison of the survival rates of migrant and resident adult bull trout suggested that when migrant adult survival was less than $(<) 0.7$, the resident survival become more influential on the estimated adult abundance (fig. 7A). In contrast, survival of subadult brook trout was not influential compared to migrant adult bull trout (fig. 7B). Other examples include the equal influence of bull trout juvenile and subadult survival (fig. 7C). For subadult survival, we present migrant subadult survival, but a similar pattern was simulated for resident subadult survival. Lastly, brook trout juvenile survival had little influence on the estimated adult abundance compared to bull trout juvenile survival (fig. 7D).

We present eight graphs from the two-way response profile sensitivity analysis that represent influential parameters and the variability of optimal decisions (figs. 8 and 9). The two-way response profiles identified eradicating brook trout from Long Creek and improving downstream conditions as the optimal decision across most parameter value pairings. When considering the top two most influential parameters on the number of adult bull trout in Year 10, survival of both migrant and resident bull trout adults, the optimal decision changed to brook trout electrofishing removal in Calahan Creek and translocation of bull trout when the survival for both life history tactics was low (fig. 8A). This was a similar pattern when adult migrant bull trout survival was paired with brook trout subadults (fig. 8B). Under this pairing, however, when the migrant survival was $>0.8$, decisions changed to brook trout electrofishing removal in Long Creek and improving downstream conditions, and when the migrant survival was $>0.9$, decisions changed to simply improving downstream conditions. For other pairings, the optimal decision was consistently eradicating brook trout from Long Creek and improving downstream conditions (fig. 8C and 8D), with one exception. Regardless of values used for the pairing brook trout subadult and small adult survival in the sensitivity analysis, the optimal decision was improving downstream conditions (fig. 8E).

Decisions were relatively insensitive to assisting migrants upstream of barriers, the potential of brook trout to immigrate, improving downstream conditions, and the effectiveness of removing brook trout with electrofishing (fig. 9). Over a range of values for these components, eradicating brook trout in Long Creek and improving downstream conditions was still the most optimal decision with a few exceptions. If 35 or more adult migrant bull trout could be transported upstream on an annual basis, then eradicating brook trout and installing a barrier in Long Creek became the optimal decision. (fig. 9A and 9B). When immigration was greater than 130 brook trout per year and capture efficiency exceeded 90 percent, improving downstream conditions and removing fish with electrofishing became the optimal choice (fig. 9C). 
A

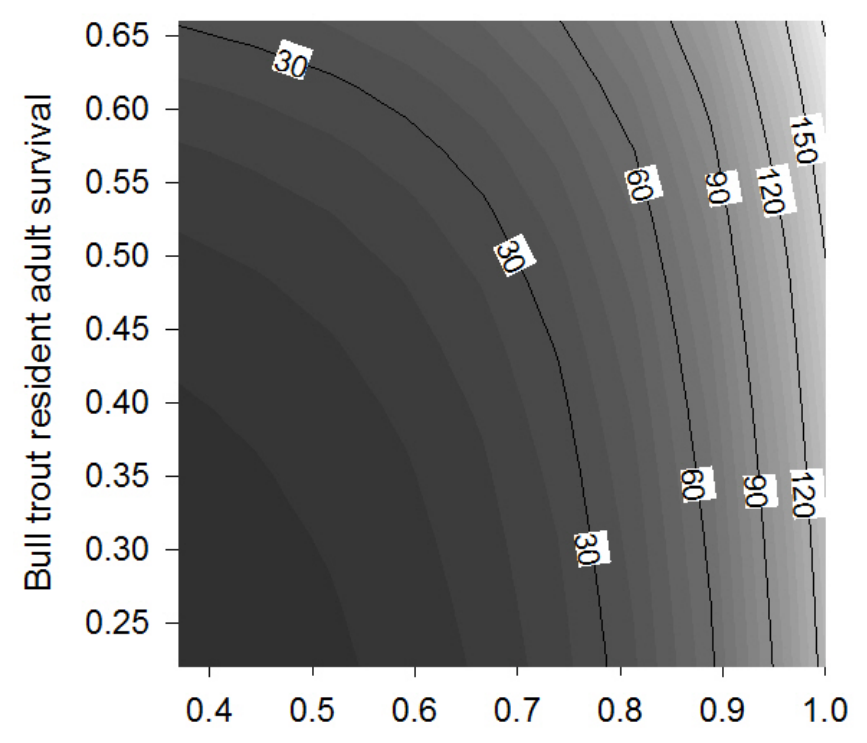

Bull trout migrant adult survival

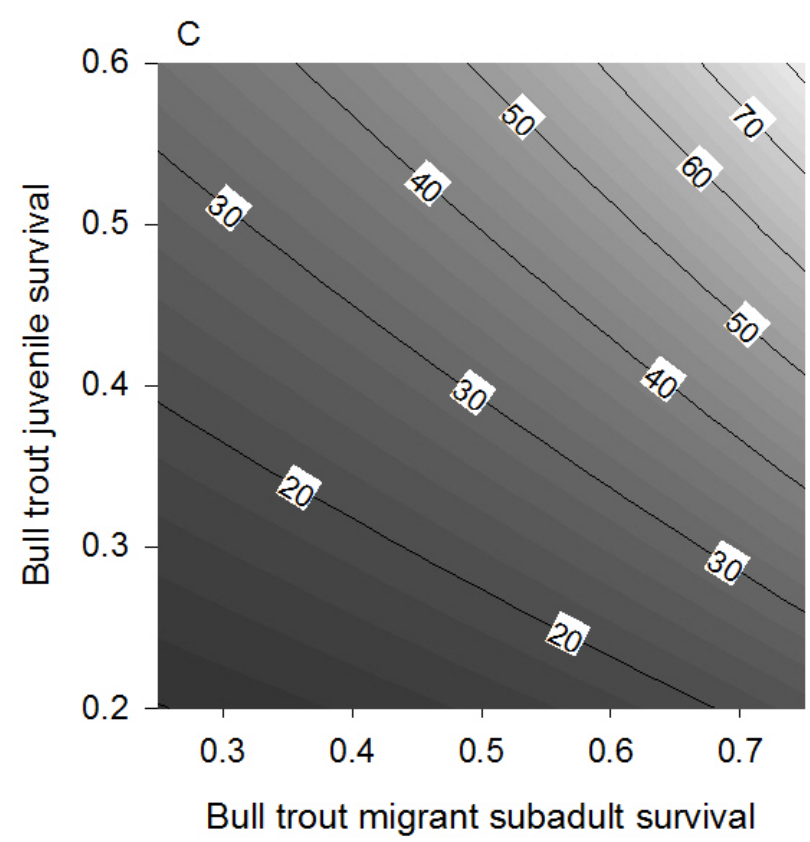

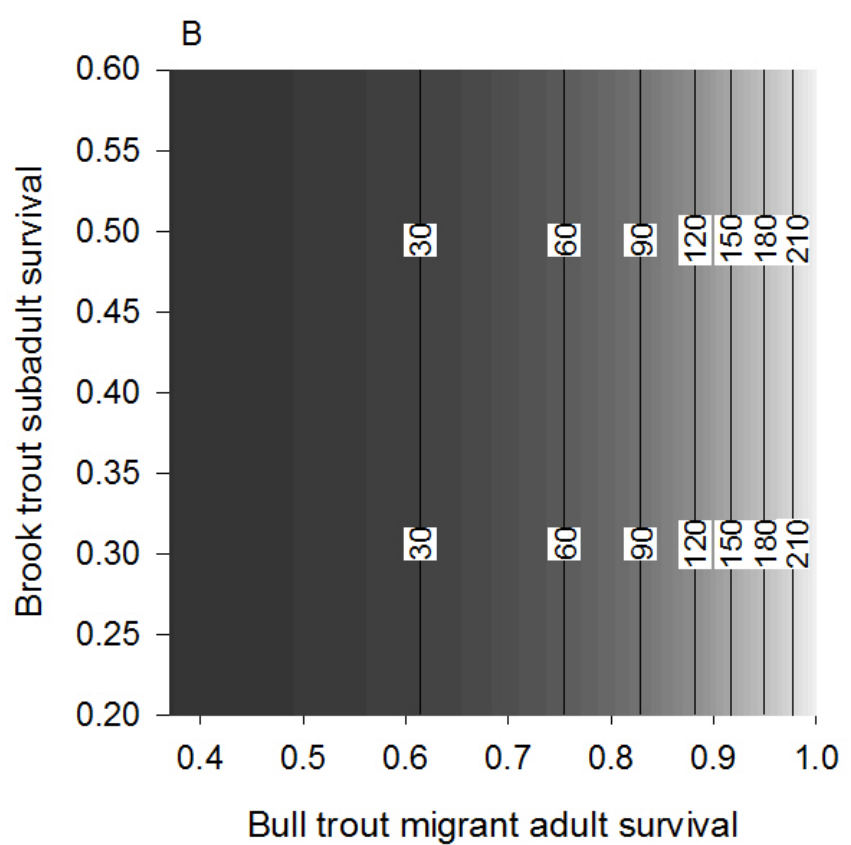

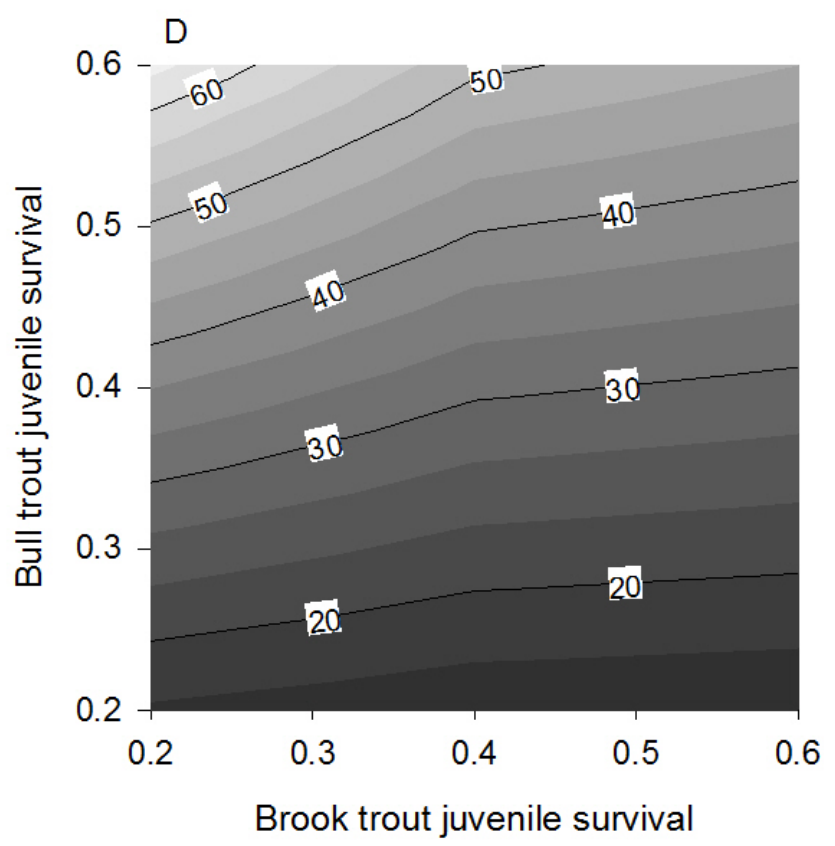

Figure 7. Two-way sensitivity analysis lines and shading represent the average number (shown in white boxes along lines) of adult bull trout at year 10 across values of pairs of decision model components, with (A) suggesting that adult resident bull trout survival had a greater influence when migrant adult bull trout survival was assumed to be low, (B) indicating that the utility was sensitive to migrant adult bull trout survival but not to subadult brook trout Survival, $(C)$ showing that the utility was equally influenced by migrant subadult and juvenile bull trout survival, and (D) indicating that juvenile brook trout survival had a very minor influence on the utility. 

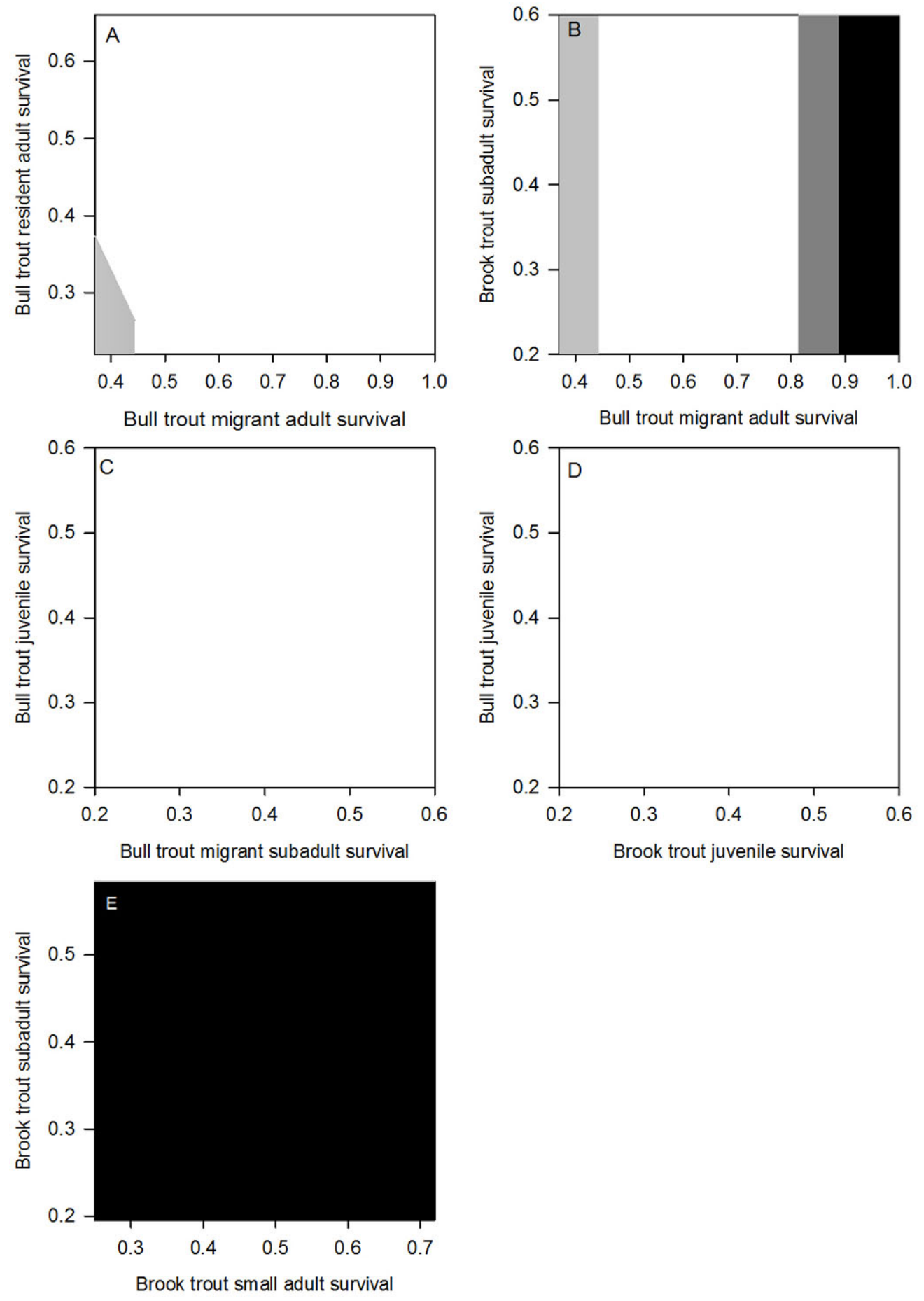

Figure 8. Two-way response profiles showing optimal decisions for select combinations of bull trout and brook trout demographics across a range of values based on maximizing adult abundance. White is improving downstream conditions and eradicating brook trout in Long Creek, light gray is removing brook trout through electrofishing in Calahan Creek and translocating subadult bull trout, dark gray is improving downstream conditions and removing brook trout through electrofishing in Long Creek, and black is improving downstream conditions. Values are averaged across the different population dynamic hypotheses. 

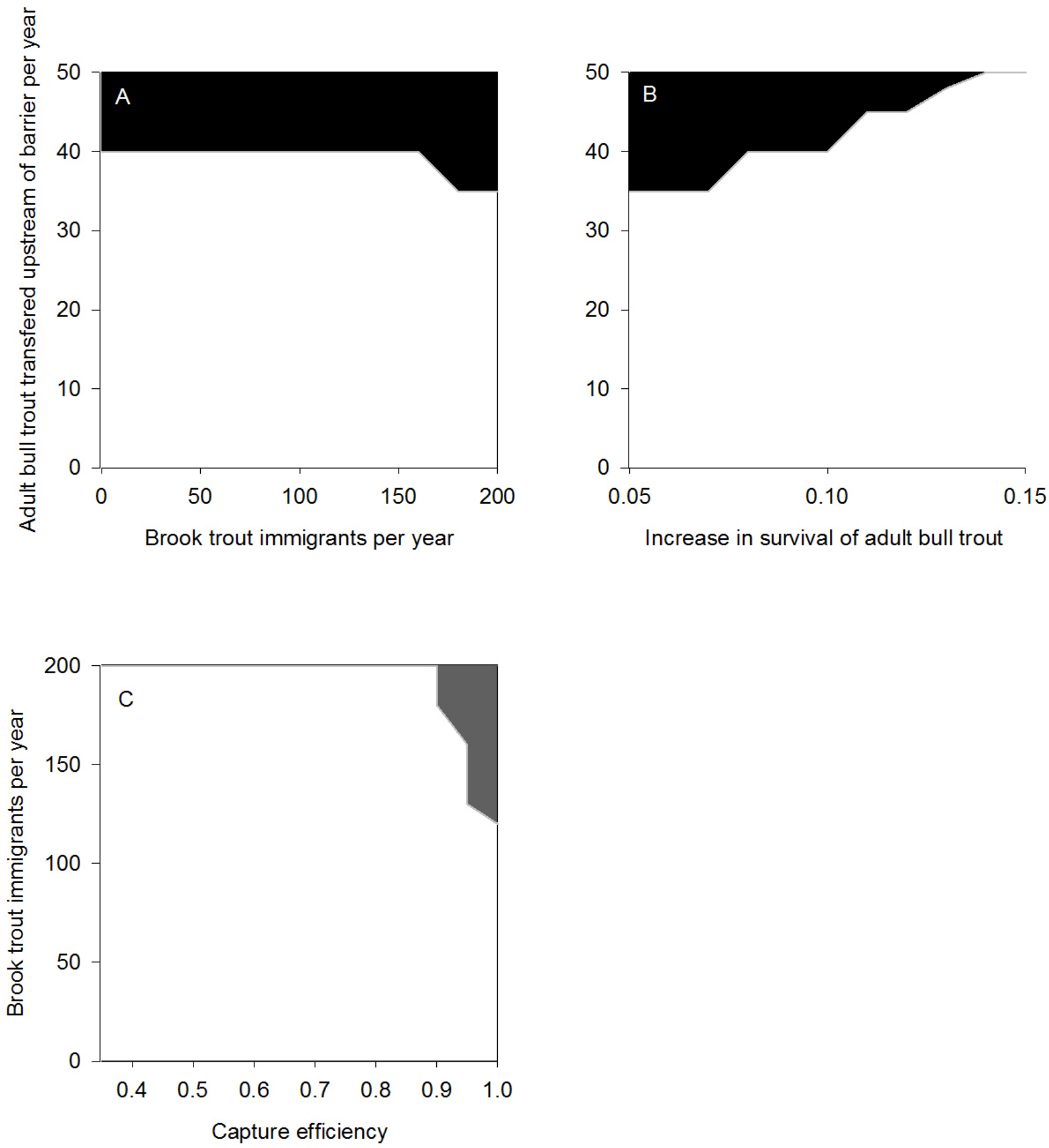

Figure 9. Two-way response profiles showing the optimal decision across a range of transporting bull trout upstream of a barrier compared to a range of bull trout immigrating upstream (A), or an increase in adult bull trout survival owing to improvements downstream (B), and bull trout immigration compared to electrofishing capture efficiency (C). White is improving downstream conditions and eradicating brook trout in Long Creek, black is installing a barrier and eradicating brook trout in Long Creek, and gray is improving downstream conditions and removing brook trout through electrofishing in Long Creek. 
Based on model results of the optimal decision for maximizing adult bull trout abundance at year 10, we developed three indifference curves (fig. 10). First, we evaluated the cost of improving downstream conditions relative to the cost of eradicating brook trout. Here, the optimal decision would be improving downstream conditions if the cost of its implementation was about 0.4 of the cost of eradicating brook trout (fig. 10A). Second, we evaluated the cost of improving downstream conditions relative to removing brook trout by electrofishing. For this comparison, the optimal decision was improving downstream conditions if it could be implemented at a cost of about 0.8 of the cost of the cost of electrofishing removal (fig. 10B). Third, we evaluated the cost of eradicating brook trout relative to their removal through electrofishing. Here, the optimal decision would be eradicating brook trout if the cost was approximately 0.03 greater than the cost of removing brook trout by electrofishing (fig. 10C).

\section{Discussion}

We used a structured decision-making approach to engage stakeholders in identifying their fundamental objectives, management alternatives, and developing models for evaluating decisions that would benefit bull trout threatened by high densities of brook trout in Long Creek, a tributary of the Sycan River in south-central Oregon. After 10 years, model simulations suggested an overarching theme among the top models, which was a need to control brook trout and ensure that the migratory tactic of bull trout can be expressed. More specifically, the optimal management decision, based on the estimated adult abundance at year 10, was to combine the eradication of brook trout from Long Creek with improvement of downstream conditions. Other top decisions included these actions independently, as well as electrofishing removal of brook trout. Moreover, sensitivity analyses suggested that these actions were consistently identified as optimal regardless of parameter values. When the ranked cost was included, the optimal decision changed to only electrofishing removal of brook trout from Long Creek, but the top decisions were similar. Taken together, these results support the conclusion that management actions focused on controlling brook trout and enhancing migrant bull trout are more likely to yield more adult bull trout within the 10-year time frame specified by stakeholders.

The importance of brook trout control may not be surprising given their high abundance in Long Creek and the known negative effects that brook trout can have on bull trout populations (Dunham and others, 2002; Warnock and Rasmussen, 2013; Kovach and others, 2016). Eradication performed better than removal through electrofishing in the model. Eradication has been successful in Sun Creek in the Klamath River Basin (Buktenica and others, 2013), but does come with potential caveats not completely considered here. For instance, unless the source for brook trout can be eradicated, a barrier will be needed to prevent recolonization in areas where brook trout are suppressed or eliminated. This could have deleterious effects on bull trout because of the potential reduction in the migratory life history expression, as our model suggests, as well as other native aquatic organisms. Moreover, efforts to eradicate brook trout could be reversed by restocking of a few individuals. Outside the system modeled herein, the potential deleterious effects of eradication using piscicides on non-target native taxa (for example, non-game fishes, freshwater mussels or other invertebrates) merit additional consideration following established guidelines (for example, Demarais and others, 1993; Finlayson and others, 2000; Britton and others 2011). 


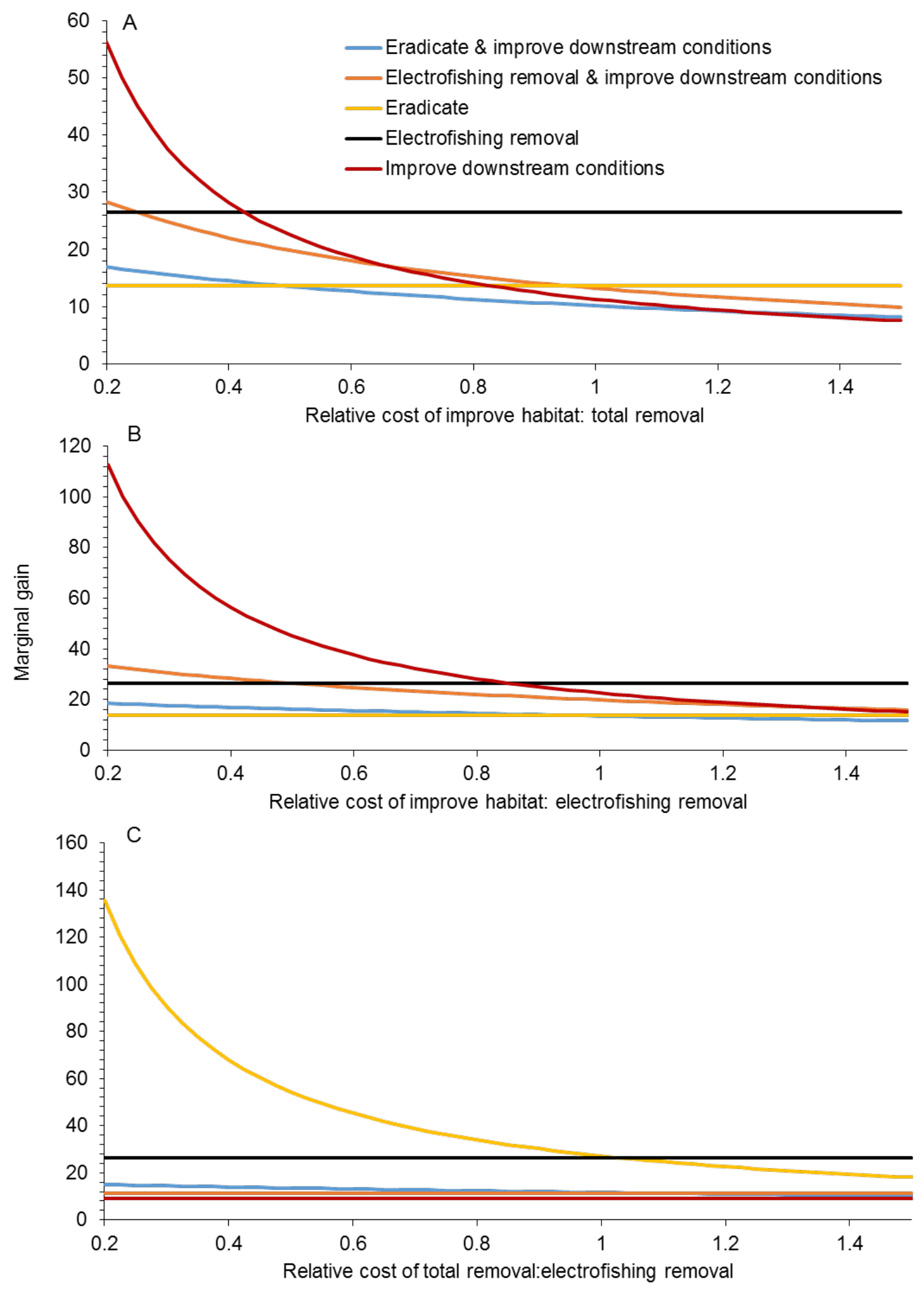

Figure 10. Graphs showing marginal gain of cost of improving downstream conditions relative to cost of eradicating brook trout (A), cost of improving downstream conditions relative to removing brook trout by electrofishing (B), and cost of eradicating brook trout relative to their removal through electrofishing (C). 
Our model did suggest that complete removal brook trout may not be necessary to benefit bull trout. As few as three electrofishing events could have enough of an effect on brook trout to improve adult bull trout abundance, at least when the brook trout population is 25 times that of bull trout. Using a similar type of Lefkovitch matrix model, Peterson, Fausch, and others (2008) suggested that 3 or more consecutive years of brook trout suppression would benefit cutthroat trout, but the effort would need to continue over time. In other words, if we ran simulations for 25 or 50 years (rather than 10 years as done for this model), the one-time, 3-year brook trout removal effort we simulated may not have been viable because the brook trout population would have returned to present abundance. To be effective, removal of brook trout may need to occur either annually or over a 5-year cycle with 3 consecutive years of removal and 2 years without removal (Peterson, Fausch, and others, 2008; but see Shepard and others, 2014). We did not consider costs beyond the 10 -year time frame specified by stakeholders in this analysis, but it is reasonable to surmise that the greater short-term costs of some alternatives (for example, eradication of brook trout, improving downstream conditions) that provide more durable results (that is, need to be completed only once) could become more cost-effective relative to alternatives that require continual investment over time (for example, removal by electrofishing). Similar results were reported by Neeson and others (2015) with respect to the benefits of larger, pulsed investments in fish passage restoration compared to longer-term trickle investments.

Improving downstream conditions was a component of the optimal management decision. The importance of this may not be surprising given that others have identified the migratory life history to be highly important in the persistence of bull trout (Rieman and McIntyre, 1993; Brenkman and Corbett, 2005; Dunham and others, 2008), and that past conservation assessments have emphasized the importance of migratory life history expression (U.S. Fish and Wildlife Service, 2008). The importance of the migratory tactic was further supported by the decline in adult bull trout numbers when a barrier was installed, and considering that a barrier may be beneficial only if 40 or more migratory adult females per year were moved upstream. However, additional analyses would need to evaluate how best to implement such actions. In the model for Long Creek, stakeholders identified that, under present conditions, migratory bull trout are small $(<240 \mathrm{~mm})$. However, at one time, the system supported large bull trout ( $>500 \mathrm{~mm}$; Light and others, 1996). These large individuals have much greater fecundity than small individuals, and if considered in the model, decisions with improving downstream conditions may become more optimal. However, sensitivity analyses revealed that an increase in fecundity alone may not be enough to maximize adult bull trout abundance. In our model, even at high fecundity ( $>500$ eggs per female), the optimal decision was still controlling brook trout and improving downstream conditions.

Regardless of the potential of improving downstream conditions to develop large migrants, the stakeholders expressed concern over the means by which such improvements could be realized. To more directly address this concern, we conducted a post-hoc survey of stakeholders and their perceptions of management alternatives for improving downstream conditions. We asked stakeholders to qualify the potential gains and probability of successful implementation for each action could be implemented downstream of the confluence of Long Creek and Sycan River (table 5). In addition, we asked stakeholders to estimate the effects of alternative means of improving downstream conditions on bull trout and brook trout size and survival (table 6). These two responses were selected because of their use in the matrix model, where size could be considered a surrogate for fecundity. Overall, stakeholders had variable opinions as to what could be accomplished and the effects on bull trout and brook trout. One action, increasing stream channel structure (for example, in-stream cover, pools), was identified among all four stakeholders with a high probability of success, although it did not appear to have a large benefit for bull trout. Regardless, stakeholders could consider the responses from this survey to help guide potential actions to improve downstream conditions. 
Table 5. Ranks of potential gains and likelihood of successful implementation for some management objectives and associated actions that could be implemented downstream section of Long Creek and the Sycan River, southcentral Oregon.

[Numbers in parentheses represent the number of stakeholders (out of a total of 4 interviewed) that identified the low, moderate, or high ranking. Stakeholder response values less than four indicate some stakeholders did not respond. Potential gains from actions are assessed within each objective and classified as follows: Increases in flow and instream habitat: High; 50-100 percent (\%); Moderate, 25-50\%; Low, less than $(<)$ 25\%. Reduce stream temperature: High, greater than $(>) 4$ degrees Celsius $\left({ }^{\circ} \mathrm{C}\right)$, Moderate, $2-4{ }^{\circ} \mathrm{C}$, Low, $<2{ }^{\circ} \mathrm{C}$. Improve biotic conditions and water quality: High, $50-100 \%$; Moderate, $25-50 \%$, Low, $<25 \%$ ]

\begin{tabular}{|c|c|c|c|}
\hline Objective & Management action & Gains in action ${ }^{1}$ & $\begin{array}{l}\text { Probability of successful } \\
\text { implementation }\end{array}$ \\
\hline \multirow[t]{2}{*}{ Increase instream flow } & Acquire instream water rights & low (2); high (2) & low (1); high (1) \\
\hline & Reduce diversion & low (1); high (3) & low (2); moderate (2) \\
\hline \multirow[t]{3}{*}{$\begin{array}{l}\text { Reduce stream } \\
\text { temperature }\end{array}$} & Increase shade & low (3) & low (1); high (2) \\
\hline & Increase flow & $\begin{array}{l}\text { low (1); } \\
\text { moderate (1); } \\
\text { high (1) }\end{array}$ & low (3) \\
\hline & Restore channel form & $\begin{array}{l}\text { low (1); } \\
\text { moderate (1); } \\
\text { high (1) }\end{array}$ & low (1); moderate (2); high (1) \\
\hline \multirow[t]{4}{*}{ Improve instream habitat } & $\begin{array}{l}\text { Restore floodplain } \\
\text { connectivity }\end{array}$ & low (2) & low (1); high (2) \\
\hline & Decrease width to depth ratio & $\begin{array}{l}\text { low (1); } \\
\text { moderate (1) }\end{array}$ & low (1); moderate (1) \\
\hline & $\begin{array}{l}\text { Increase channel instream } \\
\text { structure }\end{array}$ & low (1); high (2) & high (3) \\
\hline & Increase beaver activity & $\begin{array}{l}\text { low (2); } \\
\text { moderate (1); } \\
\text { high (1) }\end{array}$ & low (1); moderate (2); high (1) \\
\hline \multirow[t]{2}{*}{ Improve biotic conditions } & Control predators/competitors & low (1); high (2) & low (2); moderate (1) \\
\hline & Stock prey & $\begin{array}{l}\text { low (1); } \\
\text { moderate (1) }\end{array}$ & low (1); moderate (1) \\
\hline \multirow[t]{2}{*}{ Improve water quality } & Dissolved oxygen & low (2) & moderate (1) \\
\hline & Limit runoff & $\begin{array}{l}\text { low (1); } \\
\text { moderate (1) }\end{array}$ & moderate (1); high (1) \\
\hline
\end{tabular}

Other factors, such as hybridization (Leary and others, 1993) and climate change (Dunham, 2015, Isaak and others, 2015, Kovach and others, 2015) that may influence bull trout and brook trout were not explicitly considered in the model framework. However, the potential effects of these factors can be explored indirectly with the sensitivity analyses. For hybridization, it can be assumed that egg survival would decrease (that is, fewer eggs would produce pure bull trout), which can be assessed with the sensitivity analysis. Effects of climate change can be explored in a similar fashion, although climate can affect multiple life stages. Outside the 10-year time frame considered herein, it is unclear how much Long Creek will warm in the face of warming climates (Isaak and others, 2016). It is possible that climate-related loss of habitat may overwhelm the importance of factors that can be managed now (Wenger and others, 2013). Additional monitoring of thermal regimes in Long Creek (Benjamin and others, 2016) could be useful in this regard. 
Table 6. Ranked effects of different management objectives and actions on bull trout and brook trout size and survival.

\begin{tabular}{|c|c|c|c|c|c|c|c|c|c|}
\hline \multirow[t]{2}{*}{ Objective } & \multirow[t]{2}{*}{ Management action } & \multicolumn{2}{|c|}{ Bull trout maximum size ${ }^{1}$} & \multicolumn{2}{|c|}{ Bull trout survival ${ }^{2}$} & \multicolumn{2}{|c|}{ Brook trout maximum size ${ }^{3}$} & \multicolumn{2}{|c|}{ Brook trout survival $^{2}$} \\
\hline & & Direction & Magnitude & Direction & Magnitude & Direction & Magnitude & Direction & Magnitude \\
\hline \multirow[t]{2}{*}{$\begin{array}{l}\text { Increase instream } \\
\text { flow }\end{array}$} & $\begin{array}{l}\text { Acquire instream water } \\
\text { rights }\end{array}$ & Increase (3) & $\begin{array}{l}\text { low (1); moderate } \\
\text { (2) }\end{array}$ & Increase (3) & low (2); high (1) & Increase (3) & moderate (3) & Increase (3) & $\begin{array}{l}\text { moderate (2); } \\
\text { high (1) }\end{array}$ \\
\hline & Reduce diversion & Increase (3) & $\begin{array}{l}\text { low (1); moderate } \\
\text { (1); high (1) }\end{array}$ & Increase (3) & $\begin{array}{l}\text { low (1); moderate } \\
\text { (1); high (2) }\end{array}$ & Increase (3) & moderate (3) & Increase (3) & $\begin{array}{l}\text { low (1); moderate } \\
\text { (1); high (1) }\end{array}$ \\
\hline \multirow[t]{3}{*}{$\begin{array}{l}\text { Reduce stream } \\
\text { temperature }\end{array}$} & Increase shade & Increase (2) & low (2) & Increase (2) & low (2); high (1) & $\begin{array}{l}\text { Increase (1); } \\
\text { Decrease (1) }\end{array}$ & low (2) & $\begin{array}{l}\text { Increase (1); } \\
\text { Decrease (1) }\end{array}$ & low (2) \\
\hline & Increase flow & Increase (2) & $\begin{array}{l}\text { low (1); moderate } \\
\text { (1) }\end{array}$ & Increase (2) & low (2); high (1) & Increase (2) & low (2) & Increase (2) & $\begin{array}{c}\text { low (1); moderate } \\
\text { (1) }\end{array}$ \\
\hline & Restore channel form & Increase (2) & $\begin{array}{l}\text { low (1); moderate } \\
\text { (1) }\end{array}$ & Increase (2) & $\begin{array}{c}\text { low (1); moderate } \\
\text { (1) }\end{array}$ & $\begin{array}{l}\text { Increase (1); } \\
\text { Decrease (1) }\end{array}$ & low (2) & $\begin{array}{l}\text { Increase (1); } \\
\text { Decrease (1) }\end{array}$ & $\begin{array}{c}\text { low (1); moderate } \\
\text { (1) }\end{array}$ \\
\hline \multirow[t]{4}{*}{$\begin{array}{l}\text { Improve } \\
\text { instream Habitat }\end{array}$} & $\begin{array}{l}\text { Restore floodplain } \\
\text { connectivity }\end{array}$ & Increase (2) & low (2) & Increase (2) & low (2) & Increase (2) & $\begin{array}{l}\text { low (1); moderate } \\
\text { (1) }\end{array}$ & Increase (2) & $\begin{array}{c}\text { low (1); moderate } \\
\text { (1) }\end{array}$ \\
\hline & $\begin{array}{l}\text { Decrease width to depth } \\
\text { ratio }\end{array}$ & Increase (2) & $\begin{array}{l}\text { low (1); moderate } \\
\text { (1) }\end{array}$ & Increase (2) & low (2) & $\begin{array}{l}\text { Increase (1); } \\
\text { Decrease (1) }\end{array}$ & $\begin{array}{l}\text { low (1); moderate } \\
\text { (1) }\end{array}$ & $\begin{array}{l}\text { Increase (1); } \\
\text { Decrease (1) }\end{array}$ & low (2) \\
\hline & $\begin{array}{l}\text { Increase channel } \\
\text { instream structure }\end{array}$ & Increase (2) & $\begin{array}{l}\text { low (1); moderate } \\
\text { (1) }\end{array}$ & Increase (2) & $\begin{array}{l}\text { low (1); moderate } \\
\text { (1) }\end{array}$ & Increase (2) & $\begin{array}{l}\text { low (1); moderate } \\
\text { (1) }\end{array}$ & Increase (2) & $\begin{array}{c}\text { low (1); moderate } \\
\text { (1) }\end{array}$ \\
\hline & Increase beaver activity & $\begin{array}{l}\text { Increase (1); } \\
\text { Decrease (1) }\end{array}$ & $\begin{array}{l}\text { low (1); moderate } \\
\text { (1) }\end{array}$ & $\begin{array}{l}\text { Increase (1); } \\
\text { Decrease (1) }\end{array}$ & $\begin{array}{l}\text { low (1); moderate } \\
\text { (1) }\end{array}$ & Increase (2) & moderate (2) & Increase (2) & moderate (2) \\
\hline \multirow[t]{2}{*}{$\begin{array}{l}\text { Improve Biotic } \\
\text { conditions }\end{array}$} & $\begin{array}{l}\text { Control } \\
\text { predators/competitors }\end{array}$ & Increase (2) & low (1); high (1) & Increase (2) & low (1); high (1) & Decrease (2) & $\begin{array}{l}\text { low (1); moderate } \\
\text { (1) }\end{array}$ & Decrease (2) & $\begin{array}{l}\text { low(1); moderate } \\
\text { (1); high (1) }\end{array}$ \\
\hline & Stock prey & Increase (2) & $\begin{array}{l}\text { low (1); moderate } \\
\text { (1) }\end{array}$ & Increase (2) & low (2) & Increase (2) & $\begin{array}{l}\text { low (1); moderate } \\
\text { (1) }\end{array}$ & Increase (2) & low (2) \\
\hline \multirow[t]{2}{*}{$\begin{array}{l}\text { Imporve water } \\
\text { quality }\end{array}$} & Dissolved oxygen & Increase (1) & low (1) & Increase (1) & moderate (1) & Increase (1) & low (1) & Increase (1) & low (1) \\
\hline & Limit runoff & Increase (2) & $\begin{array}{c}\text { low (1); moderate } \\
\text { (1) }\end{array}$ & Increase (2) & low (2) & Increase (2) & $\begin{array}{c}\text { low (1); moderate } \\
\text { (1) }\end{array}$ & Increase (2) & low (2) \\
\hline
\end{tabular}

${ }^{1}$ Migratory bull trout maximum size is classified as follows: "High" = >700 millimeters (mm), "Moderate" = 500-700 mm, "Low" $=$ less than $(<) 500 \mathrm{~mm}$.

${ }^{2}$ Changes in survival (increase for bull trout; decrease for brook trout) are classified as follows: "High" = greater than $(>) 10$ percent $(\%)$, "Moderate" = 5-10\%, Low $=<5 \%$.

${ }^{3}$ Brook trout maximum size is classified as follows: "High" $=>500 \mathrm{~mm}$, "Moderate" $=200-500 \mathrm{~mm}$, "Low" $=<200 \mathrm{~mm}$. 
Inferences about a management decision are dependent on parameters considered, the structure of the models used, and the parameter values used. We used a relatively simple demographic model to describe bull trout and brook trout in Long Creek and the consequences of alternative management actions for their abundance. Stakeholder engagement was used throughout the modeling process to ensure that the model applied to relevant decisions, assumptions, and scenarios. A more complex model may have revealed similar results, but can make interpretation more difficult. In addition, the model was deterministic. Future evaluations could consider incorporating stochasticity to account for potential dynamics not included in this model. This could be particularly important for persistence of bull trout when population sizes are very low (Rieman and McIntyre, 1993). As for parameter values considered here, based on sensitivity analyses, the optimal decisions were consistent regardless of values used, suggesting that the robustness of the controlling brook trout and improving downstream conditions for Long Creek would provide the most benefit to bull trout over the next 10 years.

The structured decision-making process applied here allowed stakeholders from various entities to consensually identify the decision situation and objectives, as well as a suite of general actions that could be implemented. Moreover, through communication, the stakeholders were able to construct a conceptual model that was transparent and tractable because of a mutual agreement on model linkages and parameters used. It is the responsibility of managers to consider the tradeoffs in risk among the alternatives along with the uncertainty presented here to identify an initial preferred management strategy. Lastly, the current model represents the foundation for adaptive management, where implementation of the optimal management action(s) will be followed with monitoring to provide new information that will update the decision model and identify future actions after the 10 year period represented in the model.

\section{Acknowledgments}

We thank Nolan Banish, Craig Bienz, Mark Buktenica, Lon Casebeer, Dave Hering, Bill Tinniswood, Terry Smith, and Dallas Sutphin for participation in stakeholder workshops and comments on the model iterations; and Shaun Clements, Helen Neville, and Jeremy Voeltz for providing comments on earlier drafts of this report.

\section{References Cited}

Al-Chokhachy, R., and Budy, P., 2008, Demographic characteristics, population structure, and vital rates of a fluvial population of bull trout in Oregon; Transactions of the American Fisheries Society, v. 137, p. 1,709-1,722.

Benjamin, J.R., Heltzel, J. M., Dunham, J.B., Heck, M., and Banish, N., 2016, Thermal regimes, nonnative trout, and their influences on native bull trout in the upper Klamath River basin, Oregon: Transactions of the American Fisheries Society, v. 145, p. 1,318-1,330.

Brenkman, S.J., and Corbett, S.C., 2005, Extent of anadromy in bull trout and implications for conservation of a threatened species: North American Journal of Fisheries Management, v. 25, p. 1,073-1,081.

Britton, J.R., Gozlan, R.E., and Copp, G.H., 2011, Managing non-native fish in the environment: Fish and Fisheries, v. 12, p. 256-274.

Bowerman, T., 2013, Multi-scale investigation of factors limiting bull trout viability: Logan, Utah State University, Ph.D. dissertation, 209 p. 
Buchanan, D.V., Hanson, M.L., and Hooton, R.M., 1997, Status of Oregon's bull trout: Portland, Oregon Department of Fish and Wildlife, 185 p.

Buktenica, M.W., Hering, D.K., Girdner, S.F., Mahoney, B.D., and Rosenlund, B.D., 2013, Eradication of nonnative brook trout with electrofishing and antimycin-A and the response of a remnant bull trout population: North American Journal of Fisheries Management, v. 33, p. 117-129.

Chapman, B.B., Brönmark, C., Nilsson, J., and Hansson, L., 2011, The ecology and evolution of partial migration: Oikos, v. 120, p. 1,764-1,775.

Conroy, M.J., and Peterson, J.T., 2013, Decision making in natural resource management-A structured, adaptive approach: West Sussex, United Kingdom, Wiley-Blackwell, 456 p.

Demarias, B.D., Dowling, T.E., and Minckley, W.L., 1993, Post-perturbation genetic changes in populations of endangered Virgin River chubs: Conservation Biology, v. 7, p. 334-341.

Dunham, J.B., 2015, Rangewide climate vulnerability assessment for threatened bull trout: Final Report to Northwest Climate Science Center, p. 1-47. [Also available at https://nccwsc.usgs.gov/displayproject/4f8c64d2e4b0546c0c397b46/5006f464e4b0abf7ce733f90.]

Dunham, J.B., Adams, S.B., Schroeter, R.E., and Novinger, D.C., 2002, Alien invasions in aquatic ecosystems - Towards an understanding of brook trout invasions and potential impacts on inland cuttroat trout in western North America: Reviews in Fish Biology and Fisheries, v. 12, p. 373-391.

Dunham, J., Baxter, C., Fausch, K., Fredenberg, W., Kitano, S., Koizumi, I., Morita, K., Nakamura, N., Rieman, B., Savvaitova, K., Stanford, J., Taylor, E., and Yamamoto, S, 2008, Evolution, ecology, and conservation of Dolly Varden, white spotted char, and bull trout: Fisheries, v. 33, p. 537-550.

Falke, J.A., Flitcroft, R.L., Dunham, J.B., McNyset, K.M., Hessburg, P.F., and Reeves, G.H., 2015, Climate change and vulnerability of bull trout (Salvelinus confluentus) in a fire-prone landscape: Canadian Journal of Fisheries and Aquatic Sciences, v. 72, p. 304-318.

Fahrig, L., 2003, Effects of habitat fragmentation on biodiversity: Annual Review of Ecology, Evolution, and Systematics, v. 34, p. 487-515.

Fausch, K.D., 2008, A paradox of trout invasions in North America: Biological Invasions, v. 10, p. 685-701.

Fausch, K.D., Rieman, B.E., Dunham, J.B., Young, M.K., and Peterson, D.P., 2009, Invasion versus isolation - Trade-offs in managing native salmonids with barriers to upstream movement: Conservation Biology, v. 23, p. 859-870.

Finlayson, B.J., Schnick, R.A., Cailteux, R.L., DeMong, L., Horton, W.D., McClay, W., Thompson, C.W., and Tichacek, G., 2000, Rotenone use in fisheries managementAdministrative and technical guidelines manual: American Fisheries Society. 199 p. Gregory, R., Failing, L., Harstone, M., Long, G., McDaniels, T., and Ohlson, D., 2012, Structured decision making-A practical guide to environmental management choices: West Sussex, United Kingdom, Wiley-Blackwell, 299 p.

Isaak, D.J., Young, M.K., Nagel, D.E., Horan, D.L., and Groce, M.C., 2015, The cold-water climate shield-Delineating refugia for preserving salmonid fishes through the 21 st century: Global Change Biology, v. 21, p. 2,540-2,553. 
Isaak, D.J., Young, M.K., Luce, C.H., Hostetler, S.W., Wenger, S.J., Peterson, E.E., Ver Hoef, J.M., Groce, M.C., Horan, D.L., and Nagel, D.E., 2016, Slow climate velocities of mountain streams portend their role as refugia for cold-water biodiversity: Proceedings of the National Academy of Sciences, v. 113, no. 16, p. 4374-4379.

Johnston, F.D., and Post, J.R., 2009, Density-dependence life-history compensation of an iteroparous salmonid: Ecological Applications, v. 19, p. 449-467.

Johnston, F.D., Post, J.R., Mushens, C.J., Stelfox, J.D., Paul, A.J., and Lajeunesse, B., 2007, The demography of recovery of an overexploited bull trout, Salvelinus confluentus, population: Canadian Journal of Fisheries and Aquatic Sciences, v. 64, p. 113-126.

Kendall, N.W., McMillan, J.R., Sloat, M.R., Buehrens, T.W., Quinn, T.P., Pess, G.R., Kuzishchin, K.V., McClure, M.M., and Zabel, R.W., 2015, Anadromy and residency in steelhead and rainbow trout (Oncorhynchus mykiss) - A review of the processes and patterns: Canadian Journal of Fisheries and Aquatic Sciences, v. 72, p. 1-24.

Kovach, R.P., Muhlfeld, C.C., Wade, A.A., Hand, B.K., Whited, D.C., DeHaan, P.W., AlChokhachy, R. and Luikart, G., 2015, Genetic diversity is related to climatic variation and vulnerability in threatened bull trout: Global Change Biology, v. 21, p. 2,510-2,524.

Kovach, R.P., Al-Chokhachy, R., Whited, D.C., Schmetterling, D.A., Dux, A.M., and Muhlfeld, C.C., 2016, Climate, invasive species and land use drive population dynamics of a cold water specialist: Journal of Applied Ecology, v. 54, p. 638-647.

Leary, R.F., Allendorf, F.W., and Forbes, S.H., 1993, Conservation genetics of bull trout in the Columbia and Klamath River drainages: Conservation Biology, v. 7, p. 856-865.

Lee, D.C., and Rieman, B.E., 1997, Population viability assessment of salmonids by using probabilistic networks: North American Journal of Fisheries Management, v. 17, p. 1,144 1,157 .

Lefkovitch, L., 1965, The study of population growth in organisms grouped by stages: Biometrics, v. 21, p. 1-18.

Light, J., Herger, L., and Robinson, M., 1996, Upper Klamath Basin bull trout conservation strategy. Part 1-A conceptual framework for recovery: Klamath Falls, Oregon, Klamath Basin bull Trout Working Group.

Long, J.J., and Bond, C.E., 1979, Unique fish survey-Fremont National Forest, Final Report, Cooperative Agreement No. 237, U.S. Forest Service, Pacific northwest Forest Range Experiment Station and Oregon State University, 72 p.

McMahon, T.E., Zale, A.V., Barrows, F.T., Selong, J.H., and Danehy, R.J., 2007, Temperature and competition between bull trout and brook trout - A test of the elevation refuge hypothesis: Transactions of the American Fisheries Society, v. 136, p. 1,313-1,326.

Mebane, W.J., and Sekhon, J.S., 2011, Genetic optimization using derivatives-The rgenoud package for R: Journal of Statistical Software, v. 42, p. 1-26.

Neeson, T.M., Ferris, M.C., Diebel, M.W., Doran, P.J., O’Hanley, J.R., and McIntyre, P.B., 2015, Enhancing ecosystem restoration efficiency through spatial and temporal coordination: Proceedings of the National Academy of Sciences, v. 112, p. 6,236-6,241.

Nelder, J.A., and Mead, R., 1965, A simplex method for function minimization: The Computer Journal, v. 7, p. 308-313.

Peterson, D.P., and Fausch, K.D., 2003, Upstream movement by nonnative brook trout (Salvelinus fontinalis) promotes invasion of native cutthroat trout (Oncorhynchus clarki) habitat: Canadian Journal of Fisheries and Aquatic Sciences, v. 60, p. 1,502-1,516. 
Peterson, D.P., Fausch, K.D., Watmough, J., and Cunjak, R.A., 2008, When eradication is not an option-Modeling strategies for electrofishing suppression of nonnative brook trout to foster persistence of sympatric native cutthroat trout in small streams: North American Journal of Fisheries Management, v. 28, p.1,847-1,867.

Peterson, D.P., Rieman, B.R., Dunham, J.B., Fausch, K.D., and Young, M.K., 2008, Analysis of trade-offs between threats of invasion by nonnative brook trout (Salvelinus fontinalis) and intentional isolation for native westslope cutthroat trout (Oncorrhynchus clarkii lewisi): Canadian Journal of Fisheries and Aquatic Sciences, v. 65, p. 557-573.

R Core Team, 2016, R-A language and environment for statistical computing: Vienna, $\mathrm{R}$ Foundation for Statistical Computing.

Rieman, B.E., Lee, D., Chandler, G., and Myers, D., 1997, Does wildfire threaten extinction for salmonids?-Responses of redband trout and bull trout following recent large fires on the Boise National Forest: Proceedings of the Fire Effects on Rare and Endangered Species and Habitats Conference, p. 47-57.

Rieman, B.E., and McIntyre, J.D., 1993, Demographic and habitat requirements for conservation of bull trout: U.S. Forest Service, Intermountain Research Station, Boise, Idaho, General Technical Report INT-302.

Shepard, B.B., Nelson, L.M., Taper, M.L., and Zale, A.V., 2014, Factors influencing successful eradication of nonnative brook trout from four small Rocky Mountain streams using electrofishing: North American Journal of Fisheries Management, v. 34, p. 988-997.

Tyre, A.J., Peterson, J.T., Converse, S.J., Bogich, T., Miller, D., Wood, J., Brewer, D.C., and Runge, M.C., 2011, Adaptive management of bull trout populations in the Lemhi Basin: Journal of Fish and Wildlife Management, v. 2, p. 262-281.

United States Fish and Wildlife Service, 2008, bull Trout (Salvelinus confluentus) 5-year review_-Summary and evaluation: U.S. Fish and Wildlife Service, Portland, Oregon, 55 p.

U.S. Fish and Wildlife Service, 2015a, Recovery plan for the coterminous United States population of bull trout (Salvelinus confluentus) U.S. Fish and Wildlife Service, Portland, Oregon, $179 \mathrm{p}$.

U.S. Fish and Wildlife Service, 2015b, Draft Klamath recovery unit implementation plan for bull trout recovery plan: U.S. Fish and Wildlife Service, Klamath Falls, Oregon, 34 p.

Warnock, W.G., and Rasmussen, J.B., 2013, Assessing the effects of fish density, habitat complexity, and current velocity on interference competition between bull trout (Salvelinus confluentus) and brook trout (Salvelinus fontinalis) in an artificial stream: Canadian Journal of Zoology, v. 91, p. 619-625.

Wenger, S.J., Som, N.A., Dauwalter, D.C., Isaak, D.J., Neville, H.M., Luce, C.H., Dunham, J.B., Young, M.K., Fausch, K.D., and Rieman, B.E., 2013, Probabilistic accounting of uncertainty in forecasts of species distributions under climate change: Global Change Biology, v. 19, p. 3,343-3,354. 
Publishing support provided by the U.S. Geological Survey Science Publishing Network, Tacoma Publishing Service Center

For more information concerning the research in this report, contact the Director, Forest and Rangeland Ecosystem Science Center U.S. Geological Survey

777 NW 9th St., Suite 400

Corvallis, Oregon 97330

https://fresc.usgs.gov 
